\title{
Molecular transformation and degradation of refractory dissolved organic matter in the Atlantic and Southern Ocean
}

\author{
Oliver J. Lechtenfeld ${ }^{\mathrm{a}, 1}$, Gerhard Kattner ${ }^{\mathrm{a}}$, Ruth Flerus ${ }^{\mathrm{a}, 2}$, S. Leigh McCallister ${ }^{\mathrm{b}}$, \\ Philippe Schmitt-Kopplin ${ }^{\mathrm{c}, \mathrm{d}}$, Boris P. Koch ${ }^{\mathrm{a}, \mathrm{e}, *}$ \\ a Alfred-Wegener-Institut Helmholtz-Zentrum für Polar und Meeresforschung, Ecological Chemistry, Am Handelshafen 12, \\ D-27570 Bremerhaven, Germany \\ ${ }^{\mathrm{b}}$ Virginia Commonwealth University, Department of Biology, Center for Environmental Studies, 1000 West Cary Street, \\ Richmond, VA 23284, USA \\ ${ }^{\mathrm{c}}$ Helmholtz Zentrum München, German Research Center for Environmental Health, Institute for Ecological Chemistry, \\ Analytical BioGeoChemistry, Ingolstädter Landstraße 1, D-85764 Neuherberg, Germany \\ ${ }^{\mathrm{d}}$ Technische Universität München, Chair of Analytical Food Chemistry, Alte Akademie 10, 85354 Freising, Germany \\ ${ }^{\mathrm{e}}$ University of Applied Sciences, An der Karlstadt 8, D-27568 Bremerhaven, Germany
}

Received 6 May 2013; accepted in revised form 7 November 2013; Available online 21 November 2013

\begin{abstract}
More than $90 \%$ of the global ocean dissolved organic carbon (DOC) is refractory, has an average age of 4000-6000 years and a lifespan from months to millennia. The fraction of dissolved organic matter (DOM) that is resistant to degradation is a long-term buffer in the global carbon cycle but its chemical composition, structure, and biochemical formation and degradation mechanisms are still unresolved. We have compiled the most comprehensive molecular dataset of 197 Fourier transform ion cyclotron resonance mass spectrometry (FT-ICR MS) analyses from solid-phase extracted marine DOM covering two major oceans, the Atlantic sector of the Southern Ocean and the East Atlantic Ocean (ranging from $50^{\circ} \mathrm{N}$ to $70^{\circ} \mathrm{S}$ ). Molecular trends and radiocarbon dating of $34 \mathrm{DOM}$ samples (comprising $\Delta^{14} \mathrm{C}$ values from $-229 \%$ to $-495 \%$ ) were combined to model an integrated degradation rate for bulk DOC resulting in a predicted age of $>24$ ka for the most persistent DOM fraction. First order kinetic degradation rates for 1557 mass peaks indicate that numerous DOM molecules cycle on timescales much longer than the turnover of the bulk DOC pool (estimated residence times of up to $100 \mathrm{ka}$ ) and the range of validity of radiocarbon dating. Changes in elemental composition were determined by assigning molecular formulae to the detected mass peaks. The combination of residence times with molecular information enabled modelling of the average elemental composition of the slowest degrading fraction of the DOM pool. In our dataset, a group of 361 molecular formulae represented the most stable composition in the oceanic environment ("island of stability"). These most persistent compounds encompass only a narrow range of the molecular elemental ratios $\mathrm{H} / \mathrm{C}$ (average of $1.17 \pm 0.13$ ), and $\mathrm{O} / \mathrm{C}$ (average of $0.52 \pm 0.10$ ) and molecular masses $(360 \pm 28$ and $497 \pm 51 \mathrm{Da})$. In the Weddell Sea DOC concentrations in the surface waters were low $(46.3 \pm 3.3 \mu \mathrm{M})$ while the organic radiocarbon was significantly more depleted than that of the East Atlantic, representing average surface water DOM ages of $4920 \pm 180$ a. These results are in accordance with a highly degraded DOM in the Weddell Sea surface water as also shown by the molecular degradation index $I_{\text {DEG }}$ obtained from FT-ICR MS data. Further, we identified 339 molecular formulae which probably contribute to an increased DOC concentration in the Southern Ocean and potentially reflect an accumulation or enhanced sequestration of refractory DOC in the Weddell Sea. These results will

\footnotetext{
* Corresponding author at: Alfred-Wegener-Institut Helmholtz-Zentrum für Polar und Meeresforschung, Ecological Chemistry, Am Handelshafen 12, D-27570 Bremerhaven, Germany. Tel.: +49 4714831 1346; fax: +49 47148312115.

E-mail address: Boris.Koch@awi.de (B.P. Koch).

${ }_{1}^{1}$ Present address: University of South Carolina, Department of Biological Sciences, Marine Science Program, Columbia, SC 29208 , USA.

${ }^{2}$ Present address: GEOMAR Helmholtz Centre for Ocean Research, Biological Oceanography, Düsternbrooker Weg 20, D-24105 Kiel, Germany.
} 
contribute to a better understanding of the persistent nature of marine DOM and its role as an oceanic carbon buffer in a changing climate.

(C) 2013 Elsevier Ltd. All rights reserved.

\section{INTRODUCTION}

The major fraction of marine dissolved organic carbon (DOC) is present in the deep sea below $1000 \mathrm{~m}$ and constitutes $72 \%$ of the total organic carbon in the oceans, equivalent to about $477 \mathrm{Pg} \mathrm{C}$ (Hansell et al., 2009). This DOC is highly persistent with an average age of 4000-6000 years (a) and concentrations of 34-45 $\mu \mathrm{M} \mathrm{C}$ (Druffel et al., 1992; Hansell et al., 2012). Most of the DOC is derived from primary producers using dissolved inorganic carbon (DIC) as their carbon source. It is directly released into the oceans from photosynthetic plankton or through heterotrophic transformation processes (Carlson, 2002) and also transported from land by rivers (Hedges et al., 1997) and through the atmosphere (Willey et al., 2000) with minor allochthonous and autochthonous sources in the deep ocean (e.g., Hansman et al., 2009; Pohlman et al., 2011). On the shelves and in the pelagic ocean the majority of new DOC is remineralized to $\mathrm{CO}_{2}$ mainly by heterotrophs (respiration from prokaryotes or higher trophic level organisms; del Giorgio and Duarte, 2002) with a small contribution from photodegradation (Mopper et al., 1991), or it is transformed to a fraction of degraded dissolved organic matter (DOM) that is highly resistant to microbial decomposition (Jiao et al., 2010). This fraction is generally termed refractory or recalcitrant DOC (RDOC) and model studies suggest that RDOC comprises more than $90 \%$ of the global ocean DOC inventory (Hansell et al., 2012). The transfer of fresh organic matter into persistent forms (refractory dissolved organic matter, RDOM) gives rise to a fraction of reduced carbon being a slowly exchanging carbon pool in the ocean. In contrast to DIC, which is in exchange with the atmosphere on average every ocean mixing cycle, RDOC remains for geological times in the ocean. Furthermore, enhanced microbial production of RDOM might balance the expected loss of inorganic buffer capacity related to a warmer and more acid ocean in the future (Sabine et al., 2004; Jiao et al., 2010).

To assess the various sources and fluxes between different pools of DOM, radiocarbon $\left({ }^{14} \mathrm{C}\right)$ dating of bulk DOC or of fraction/compound specific isolates of DOC is commonly applied (e.g., Loh et al., 2004; Repeta and Aluwihare, 2006; Walker et al., 2011). These studies revealed a size-age relationship of DOM with distinct chemical fractions covering a wide range of ages from modern to radiocarbon depleted values. However, on the molecular level, the distribution of radiocarbon within DOM fractions is not resolved and remains a major scientific challenge (Bauer, 2002; McNichol and Aluwihare, 2007). Full depth profiles of bulk $\mathrm{DO}^{14} \mathrm{C}$ revealed fundamentally different processes compared to dissolved inorganic $\left(\mathrm{DI}^{14} \mathrm{C}\right)$ and particulate organic radiocarbon $\left(\mathrm{PO}^{14} \mathrm{C}\right.$; Druffel et al., 1992; Beaupré and Aluwihare, 2010). Although similar in shape, the depth profiles of DOC $\Delta^{14} \mathrm{C}$ are typically depleted by about $300 \%$ relative to DIC $\Delta^{14} \mathrm{C}$ throughout the water column. Furthermore, the calculated transit time from the deep North Atlantic to the deep Pacific Ocean is $\sim 1300$ a for $\mathrm{DI}^{14} \mathrm{C}$ while it is $\sim 2000$ a for $\mathrm{DO}^{14} \mathrm{C}$ (Stuiver et al., 1983; Bauer et al., 1992). This discrepancy highlights the different mechanisms of formation, removal and transformation of the dissolved organic compared to the dissolved inorganic carbon pool.

If the degradation of DOC is independent of its age, any decrease in DOC $\Delta{ }^{14} \mathrm{C}$ is expected to result in an accordant decrease in the DOC concentration (the relation is always exponential due to the conversion from $\Delta^{14} \mathrm{C}$ to radiocarbon age). However, the only published full depth profile from the Southern Ocean indicates that the surface and deep waters in the Antarctic Circumpolar Current are particularly depleted in radiocarbon (Druffel and Bauer, 2000). Especially compared to other deep ocean sites in the Atlantic and Pacific, the ratios of DOC $\Delta^{14} \mathrm{C}$ and DOC concentrations are lower (more negative) in the deep Southern Ocean. Furthermore, the surface DOC $\Delta^{14} \mathrm{C}$ values are lower by about $160 \%$ compared to the Sargasso Sea (Bauer et al., 1992) which was explained by vertical mixing processes of old, radiocarbon depleted DOC and the small surplus of freshly produced surface DOC with a recent radiocarbon signature (Druffel and Bauer, 2000). Despite intense spring phytoplankton blooms during winter seaice retreat (Lochte et al., 1997; Arrigo et al., 2008; Geibert et al., 2010), the Southern Ocean surface DOC concentrations are among the lowest in the global ocean (Ogawa et al., 1999; Hansell, 2002). Only a little seasonal accumulation has been observed in the Ross Sea (Carlson et al., 1998, 2000) and the Weddell Sea (Kähler et al., 1997). Although polar waters have lower bacterial growth rates compared to temperate ocean regimes (Kirchman et al., 2009), this has been explained by enhanced partitioning of primary production into the POC pool (Carlson et al., 1998) and an efficient heterotrophic removal of the intra-seasonally generated, semi-labile DOC (Kähler et al., 1997).

DOM transformation processes were also studied in situ by the direct analysis of biomolecules (e.g., amino acids, carbohydrates) and their known degradation products (e.g. Goldberg et al., 2011; Kaiser and Benner, 2012) or via experimental degradation approaches (e.g., Gruber et al., 2006; Kawasaki and Benner, 2006; Davis et al., 2009). The spatiotemporal variability of biomolecules and net removal rates of DOC or distinct fractions (e.g., Amon and Benner, 1994; Loh et al., 2004; Kaiser and Benner, 2009; Hansell, 2013) corroborated the concepts of age-, size- and reactivity continua in which the microbial carbon pump (Jiao et al., 2010) plays a major role in transforming fresh into refractory organic matter. As a result of the global thermohaline circulation pattern, deep water masses are 
exchanged on a millennial time scale. After roughly 1000 a, any DOM imprinted water mass will become surface water again where fresh DOM is added and old, refractory DOM compounds are at least in part reused and replaced, resetting the mean age and mean composition of the DOM pool. Thus the transport of large amounts of DOC with the global thermohaline circulation prevents an in situ study of the long-term decay of distinct compounds.

Fourier transform ion cyclotron resonance mass spectrometry (FT-ICR MS) has opened a new analytical window to identify molecular formulae of thousands of marine compounds which are not accessible using standard analytical techniques (e.g., Koch et al., 2005, 2008; Hertkorn et al., 2006; Kujawinski et al., 2009; D'Andrilli et al., 2010). Currently, much effort is undertaken to overcome the analytical restrictions of this technique (Kido Soule et al., 2010; Sleighter et al., 2010, 2012; Tfaily et al., 2011) and to refine the data evaluation algorithms (Kujawinski and Behn, 2006; Koch et al., 2007; Flerus et al., 2011; Tziotis et al., 2011). A particular drawback is that usually only small sample sets were analyzed, which hinders statistically robust generalizations to environmental applications.

Recently, Flerus et al. (2012) published the largest FTICR MS dataset of marine solid-phase extracted DOM (SPE-DOM) comprising 137 samples from the East Atlantic Ocean. Here we present a comprehensive ultra-high resolution dataset for the Atlantic sector of the Southern Ocean (Weddell Sea). This new dataset allows extending and refining the concepts of the DOM age model, the DOM degradation state and the DOM degradation continuum. In continuation of our previous work, at least three of the central research questions related to the microbial carbon pump (MCP) concept (Jiao et al., 2010, Box 1) are addressed with this paper:

(i) What are the concentrations, compositions and spatiotemporal variations of recalcitrant dissolved organic matter (RDOM) in the ocean? Comparing the composition of DOM in the Atlantic and Southern Ocean, we seek to reveal molecular differences related to the distinct oceanography and biogeochemistry, e.g., the substantial upwelling and accordingly mixing of aged and surface waters masses in the central Weddell Sea.

(ii) What are the structural and biochemical constraints on degradability? The degradation continuum proposes that, as a result of a continuous distribution of degradation rates, each DOM sample is composed of molecules with different ages. The combination of radiocarbon dating of DOM and ultra-high resolution mass spectrometry enables us to model degradation rates and residence times of hundreds to thousands of individual molecular formulae. Based on the molecular composition, we aim to unravel systematic variations in individual degradation rates.

(iii) Can we predict the chemical composition of the degradation products? We expect to acquire molecular chemical information (e.g., elemental composition) on the most refractory DOM compounds. These long-lived DOM compounds are highly resistant to microbial decomposition potentially resulting from a distinct chemical composition.

\section{METHODS}

\subsection{Sampling}

Water samples were collected with the rosette sampler with mounted conductivity-temperature-depth (CTD) sensors in the Atlantic sector of the Southern Ocean in December 2008 during the RV Polarstern cruise ANT-XXV/2. Samples were taken at 2, $20 \mathrm{~m}$, the fluorescence maximum (30-100 m), 200, 2000 and $55 \mathrm{~m}$ above the seafloor.

All samples were filtered using pre-combusted GF/F filters $\left(450^{\circ} \mathrm{C}, 5 \mathrm{~h} ; \sim 0.7 \mu \mathrm{m}\right.$ nominal pore size, Whatman). Samples for nutrient analysis were poisoned and stored at $4{ }^{\circ} \mathrm{C}$ (Kattner, 1999). Acidified samples ( $\mathrm{pH} 2$ with hydrochloric acid; suprapur, Merck) for DOC determinations were stored at $-20{ }^{\circ} \mathrm{C}$. Solid-phase extraction (SPE; $1 \mathrm{~g}$ Mega Bond Elut PPL, Varian) was performed according to Dittmar et al. (2008). The SPE samples (5 L water was extracted and eluted in $5 \mathrm{~mL}$ methanol; LiChrosolv, Merck) were stored at $-20{ }^{\circ} \mathrm{C}$ until FT-ICR MS analysis. The DOC extraction efficiency was $42 \pm 7 \%$ (number of samples, $\left.n_{\mathrm{s}}=187\right)$.

\subsection{DOC and nutrient analysis}

DOC was determined by high temperature catalytic oxidation (TOC-V $\mathrm{V}_{\mathrm{CPN}}$ analyzer, Shimadzu). For external calibration potassium hydrogen phthalate (KHP, Merck) was used. Aliquots of the methanol extracts $(50 \mu \mathrm{L})$ from the SPE samples were evaporated under $\mathrm{N}_{2}$ gas flow to complete dryness and subsequently redissolved in $6.5 \mathrm{~mL}$ ultrapure water for DOC analysis (SPE-DOC). All samples were acidified $\left(0.1 \mathrm{M} \mathrm{HCl}\right.$ suprapur, Merck) and purged with $\mathrm{O}_{2}$ for $>5$ min. Performance of the instrument was recorded by daily analysis of in-lab KHP standard solutions and reference samples (deep sea reference, DSR, Hansell research lab). The average instrument blank was $<1 \mu \mathrm{M} \mathrm{C}\left(n_{\mathrm{s}}=56\right)$ and repeatability of the DSR was $>95 \%\left(n_{\mathrm{s}}=42\right)$. Nutrient samples (nitrate, nitrite, phosphate, silicate) were analyzed using an autoanalyzer (Evolution III, Alliance instruments) with standard seawater methods (Kattner and Becker, 1991).

\section{3. ${ }^{14} \mathrm{C}$ measurements}

Aliquots of the SPE methanol extracts $\left(0.2 \mathrm{~mL}, n_{\mathrm{s}}=10\right)$ were transferred to pre-combusted quartz tubes $\left(500{ }^{\circ} \mathrm{C}\right.$, $6 \mathrm{~mm}$ diameter), the solvent evaporated under $\mathrm{N}_{2}$ flow, and the DOM in vacuum sealed tubes combusted to $\mathrm{CO}_{2}$ at $900{ }^{\circ} \mathrm{C}$ (with $\mathrm{CuO} / \mathrm{Ag}$; Sofer, 1980). The $\mathrm{CO}_{2}$ was subsequently reduced with $\mathrm{H}_{2}$ to graphite over a Co catalyst (Vogel et al., 1987). Graphite targets were analyzed for ${ }^{14} \mathrm{C}$ at the Center for Accelerator Mass Spectrometry at Lawrence Livermore National Laboratory. $\Delta^{14} \mathrm{C}$ values were reported according to the conventions of Stuiver and Polach (1977). SPE-DOC blanks did not yield any detectable amount of carbon. 


\subsection{FT-ICR MS measurements}

Sixty SPE-DOM samples from the Southern Ocean were analyzed using a FT-ICR mass spectrometer (Apex Qe, Bruker Daltonics, Billerica, MA), equipped with a $12 \mathrm{~T}$ refrigerated actively shielded superconducting magnet (Bruker Biospin, Wissembourg, France). An Apollo II dual electrospray source (ESI, Bruker) was used in negative ion mode (capillary voltage: $-4200 \mathrm{~V}$, infusion flow rate: $\left.2 \mu \mathrm{L} \mathrm{min}{ }^{-1}\right)$. Prior to measurement, the extracts were diluted with methanol (LiChrosolv, Merck) to get the same SPE-DOC concentrations for all samples. For one spectrum 512 scans were added in the mass range $147-2000 \mathrm{~m} / \mathrm{z}$ and the acquired spectra were externally calibrated with arginine cluster. NOM experiments performed under the same instrumental configuration yielded a relative mass peak magnitude repeatability of 5\% needed for chemometric approaches (Rossello-Mora et al., 2008). To achieve an optimum in comparability of marine DOM analysis we internally recalibrated the spectra with masses that were repeatedly found in marine DOM samples (Koch et al., 2008; Flerus et al., 2011). The standard deviation of the mass error of the calibration masses was $<0.2 \mathrm{ppm}$. To optimize the ability to compare this large set of DOM spectra, all samples from the Southern and East Atlantic Ocean were measured successively.

\subsection{FT-ICR MS data evaluation}

All ions were singly charged as confirmed by the spacing of the related ${ }^{12} \mathrm{C}_{n}$ and ${ }^{13} \mathrm{C}^{12} \mathrm{C}_{n-1}$ mass peaks. The mass spectra were evaluated in the range $200-600 \mathrm{~m} / \mathrm{z}$ according to Flerus et al. (2012). Briefly, molecular formulae were calculated from the $m / z$ values with a home-built algorithm allowing for the elemental combinations ${ }^{12} \mathrm{C}_{0-50}{ }^{13} \mathrm{C}_{0-1}{ }^{1} \mathrm{H}_{0-120}{ }^{14} \mathrm{~N}_{0-2}$ ${ }^{16} \mathrm{O}_{0-35}{ }^{34} \mathrm{~S}_{0-1}$ with a mass accuracy $|\Delta m| \leqslant 0.5 \mathrm{ppm}$. The "nitrogen-rule" and elemental ratios $\mathrm{O} / \mathrm{C} \leqslant 1, \mathrm{~N} / \mathrm{C} \leqslant 1$, $\mathrm{H} \leqslant 2 \mathrm{C}+2+\mathrm{N}$ (Koch et al., 2005, 2007) were applied to all molecular formulae and ambiguously assigned mass peaks were checked with the chemical building block approach (Koch et al., 2007). Due to the high degree of spectral similarity between samples $(52 \%$ of the mass peaks were present in at least $75 \%$ of all samples) detailed data evaluation was based on normalized magnitudes. The normalized magnitude values were calculated as mass peak magnitude (i.e., intensity) divided by the summed magnitude of all mass peaks in a respective spectrum and expressed as percentage. Furthermore, only mass peaks having a normalized magnitude $\geqslant 0.01 \%$ were considered for the evaluation. On average they accounted for $96.1 \pm 0.8 \%$ of the total intensity. This approach resulted in $1391 \pm 47$ assigned mass peaks with only $1 \pm 2$ doubly assigned mass peaks for each of the 60 spectra from the Southern Ocean. The summed intensity of the double assigned mass peaks is equivalent to $0.02 \pm 0.03 \%$ of the total intensity, therefore introducing only negligible effects on the average elemental ratios. Intensity weighted average (wa) molecular masses and elemental ratios were calculated from the normalized peak magnitudes. Double bond equivalents (DBE, representing the sum of $\pi$-bonds and rings in a neutral molecule) were calculated according to the following equation: $\mathrm{DBE}=1+1 / 2(2 \mathrm{C}-\mathrm{H}+\mathrm{N})$ where $\mathrm{C}, \mathrm{H}$ and $\mathrm{N}$ are the number of carbon, hydrogen and nitrogen atoms in a molecular formula. Carboxyl groups $(\mathrm{COOH})$ have been identified as the dominant oxygen-bearing functional group in marine DOM (Hedges et al., 1992) and especially in carboxyl-rich alicyclic molecules (CRAM), a major refractory component in marine DOM (Hertkorn et al., 2006). Carboxyl groups account for two oxygen atoms bound to $\mathrm{sp}^{2}$-hybridized carbon and hence we apply the quantity $\lfloor 1 / 2 \mathrm{O}\rfloor$ (floor function) to obtain a conservative estimate on the maximum possible number of $\mathrm{COOH}$ groups in a calculated molecular formula. Consequently, positive DBE- $\left\lfloor\frac{1}{2} \mathrm{O}\right\rfloor$ values indicate additional rings and/or double bonds in a molecule while negative values indicate the presence of oxygen atoms bound to $\mathrm{sp}^{3}$-hybridized carbon atoms (i.e., hydroxyl, methoxy or other ether groups).

\subsection{Age model and degradation continuum concept}

A representative subset of FT-ICR MS peaks from 24 samples from the East Atlantic Ocean (Flerus et al., 2012) was used to model the age of bulk SPE-DOM. Peak magnitudes which showed a significantly positive (POS) or negative (NEG) correlation with measured $\Delta^{14} \mathrm{C}$ values $\left(\Delta^{14} \mathrm{C}_{\text {meas }}\right)$ were subsumed and implemented in a calibration function. This function was applied to the total FT-ICR MS dataset, resulting in calculated $\Delta^{14} \mathrm{C}$ values $\left(\Delta^{14} \mathrm{C}_{\text {calc }}\right)$ for 137 East Atlantic Ocean samples $\left(\mathrm{AM}^{\mathrm{AO}}\right)$. To assure statistical robustness of the SPE-DOM age model for the Southern Ocean $\left(\mathrm{AM}^{\mathrm{SO}}\right)$, only those peaks were considered that appeared in all 10 Southern Ocean samples for which a $\Delta^{14} \mathrm{C}$ value was determined. Further, a significant Pearson's coefficient of correlation $(r)$ between normalized peak magnitude and $\Delta^{14} \mathrm{C}$ value was required $(|r|>0.65 ; p<0.05)$ to include a peak in the calibration function. For the subsequently used combined age model $\left(\mathrm{AM}^{\mathrm{AO}+\mathrm{SO}}\right.$, based on a total of $34 \Delta^{14} \mathrm{C}$ measurements), we only considered peaks which were present in $\geqslant 25$ samples showing a highly significant correlation with $\Delta^{14} \mathrm{C}(|r| \geqslant 0.5 ; p<0.01)$.

For the concept of a continuous degradation of DOM, Flerus et al. (2012) used the intrinsic molecular signatures of 137 SPE-DOM samples from the East Atlantic Ocean analyzed with FT-ICR MS. Each peak from their set of samples for which an elemental composition could be determined (2850 distinct molecular formulae) was analyzed for a statistically significant correlation with the age of the bulk SPE-DOM sample. The relative peak magnitude distribution within a sample represents the intrinsic degradation state of the respective sample. The results from Flerus et al. (2012) are strong evidence for a continuous (although not necessarily uniformly continuous) distribution of radiocarbon ages in DOM.

The degradation state of an SPE-DOM sample analyzed with ESI-(-)-FT-ICR MS can be approximated with the degradation index ( $I_{\mathrm{DEG}}$, Flerus et al., 2012). This index is comprised of five compounds from the POS peak list ( $\mathrm{POS}_{I \mathrm{DEG}}$ : $\mathrm{C}_{13} \mathrm{H}_{18} \mathrm{O}_{7}, \mathrm{C}_{14} \mathrm{H}_{20} \mathrm{O}_{7}, \mathrm{C}_{15} \mathrm{H}_{22} \mathrm{O}_{7}, \mathrm{C}_{15} \mathrm{H}_{22} \mathrm{O}_{8}$, $\left.\mathrm{C}_{16} \mathrm{H}_{24} \mathrm{O}_{8}\right)$ and the NEG peak list $\left(\mathrm{NEG}_{I D E G}: \mathrm{C}_{17} \mathrm{H}_{20} \mathrm{O}_{9}\right.$, $\mathrm{C}_{19} \mathrm{H}_{22} \mathrm{O}_{10}, \mathrm{C}_{20} \mathrm{H}_{22} \mathrm{O}_{10}, \mathrm{C}_{20} \mathrm{H}_{24} \mathrm{O}_{11}, \mathrm{C}_{21} \mathrm{H}_{26} \mathrm{O}_{11}$ ), respectively. These compounds have been found to be ubiquitously present in SPE-DOM from various sources and 
environments. Raw peak magnitudes are used to facilitate the calculation of the index:

$I_{\mathrm{DEG}}=\frac{\sum \text { magnitudes } \mathrm{NEG}_{I_{\mathrm{DEG}}}}{\sum\left(\text { magnitudes } \mathrm{NEG}_{I_{\mathrm{DEG}}}+\text { magnitudes } \mathrm{POS}_{I_{\mathrm{DEG}}}\right)}$

$I_{\mathrm{DEG}}$ provides an easy to use indicator of the overall biochemical boundary condition, from which the samples were derived. Higher $I_{\mathrm{DEG}}$ values generally correspond to a higher degree of degradation (Flerus et al., 2012). In this study, young and old DOM samples were defined by calculated radiocarbon ages of $<2500$ and $>5000$ a, respectively.

\subsection{Statistical analysis}

For multivariate statistical analyses (software "R", 2013) we used principal component analysis (PCA, Pearson, 1901) based on natural log transformed normalized magnitudes (to emphasize peaks with low magnitudes). Comparison of two sample means was performed with a Student's $t$-test and for more than two samples with a Tukey's honest significance difference test. If the sample's parameter was not normally distributed (tested with the Kruskal-Wallis test) a Mann Whitney $U$-test (two independent samples) or Wilcoxon $T$-test (paired samples) was performed. Comparison of regression model subsets was performed with an $F$-test to account for different degrees of freedom. The Null hypothesis was rejected if the test's $p$-value was below the significance level $\alpha=0.05$, unless otherwise stated.

\section{RESULTS}

\subsection{Physico-chemical parameters and SPE-DOM $\Delta^{14} \mathrm{C}$}

Each sample was assigned a geographical group ("water mass"): Samples from the Antarctic Circumpolar Current (ACC) were divided into north (NPF) and south (SPF) of the Polar Front (around $14.5^{\circ} \mathrm{E}$ and $50^{\circ} \mathrm{S}$ ). Stations south of $55^{\circ} \mathrm{S}$ (corresponding to the southern boundary of the ACC) were defined as Weddell Gyre (WG) and were characterized by their water mass properties (Foldvik et al., 1985 ) into Antarctic surface water (AASW), low salinity shelf water (LSSW), warm deep water (WDW: $0{ }^{\circ} \mathrm{C}<$ potential temperature $\left.\left(T_{\text {pot }}\right)<+0.8^{\circ} \mathrm{C}\right)$ and Weddell Sea deep water (WSDW: $T_{\text {pot }}<0{ }^{\circ} \mathrm{C}$ ). Four samples were derived from the center of a warm Agulhas ring (AR). Other samples south of the African continent and north of $-40^{\circ} \mathrm{S}$ were labeled South Atlantic Region (SAR). Fig. 1 shows the surface samples in the South-East Atlantic and Atlantic sector of the Southern Ocean and their corresponding water mass assignments. Nutrient data and a section plot with temperature profiles and DOC distributions in the upper $500 \mathrm{~m}$ of the WG/ACC are presented in the Electronic Annexes to this article (EA Table 1 and EA Fig. 1).

In the top $100 \mathrm{~m}$ of the Weddell Sea, DOC concentrations ([DOC]) varied only slightly $\left(46.3 \pm 3.3 \mu \mathrm{M}, n_{\mathrm{s}}=29\right)$ and were only slightly larger than the deep water DOC concentrations (>100 m: $\left.44.2 \pm 4.0 \mu \mathrm{M}, n_{\mathrm{s}}=47\right)$. Local surface maxima of $[\mathrm{DOC}]$ were observed in the ACC zone between about 45 and $55^{\circ} \mathrm{S}(\max .: 67 \mu \mathrm{M})$. North of the Polar Front, higher sub-surface (20-100 m) DOC concentrations

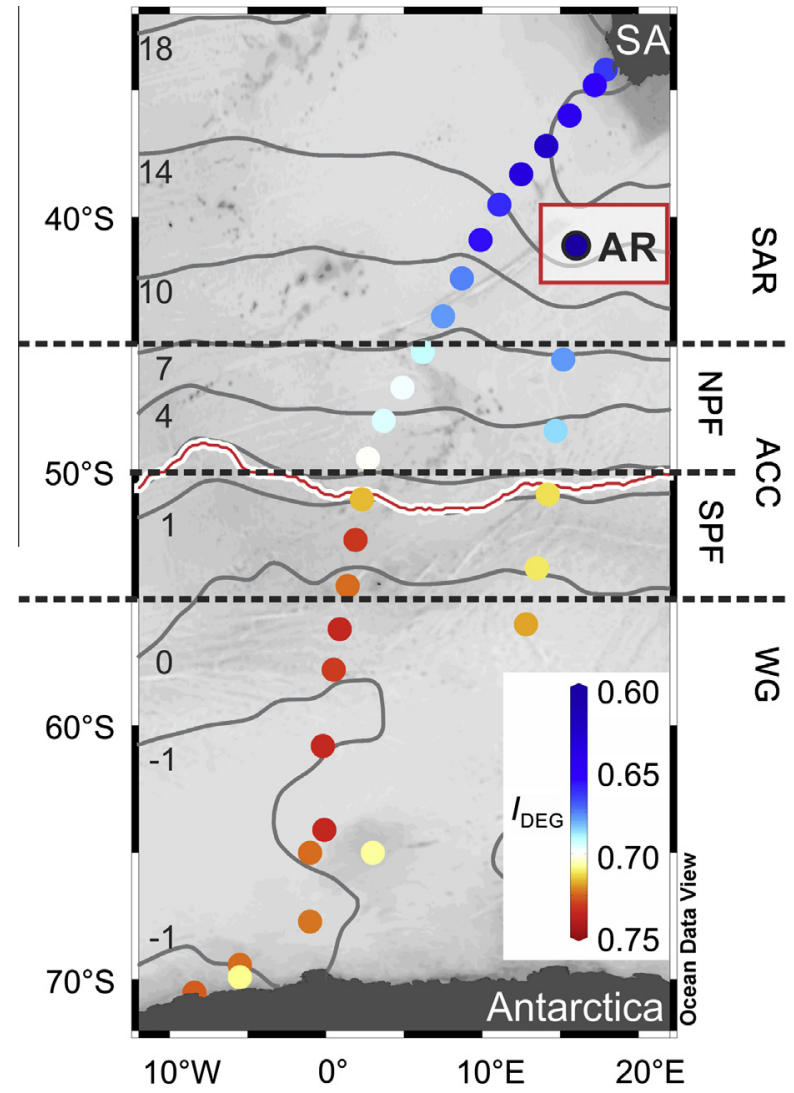

Fig. 1. Sampling stations in the South-East Atlantic and Atlantic sector of the Southern Ocean. Contour lines (grey) are the monthly means of sea surface temperature in ${ }^{\circ} \mathrm{C}$ (Data from Dec, 2008, www.esrl.noaa.gov/psd/). The red line indicates the approximate position of the Polar Front (Orsi et al., 1995). The color of the surface samples $(<11 \mathrm{~m})$ between South Africa (SA) and Antarctica represents the $I_{\text {DEG }}$ values (Flerus et al., 2012) and dashed lines mark the geographical groups SAR, NPF, SPF and WG (see text for abbreviations). The warm AR station is highlighted by the red box.

were found $\left(54.9 \pm 5.0 \mu \mathrm{M}, n_{\mathrm{s}}=11\right)$ in contrast to the SPF $\left(45.4 \pm 2.0 \mu \mathrm{M}, n_{\mathrm{s}}=11\right)$. All SPE samples from the Southern Ocean (i.e., south of $45^{\circ} \mathrm{S}$ ) revealed $\Delta^{14} \mathrm{C}$ values in the range of $-413 \%$ to $-495 \%$ (Table 1 ), equivalent to an average SPE-DOM age of $\sim 4200-5400$ a.

\subsection{FT-ICR MS results from the Southern Ocean}

All identified mass peaks in our spectra were singly charged. Therefore, and for ease of reading, we refer to the mass to charge ratio $(\mathrm{m} / \mathrm{z})$ only as "molecular mass" and to the mass peak only as "peak". The assigned molecular formulae can comprise an immense structural diversity (Hertkorn et al., 2008), making it impossible to designate chemical reactions as transformation pathways between molecular formulae. In this article, we generally refer to a calculated molecular formula as a "compound".

A total of 2363 different compounds were identified in the 60 SPE-DOM samples, 678 of which were present in all samples. On a presence/absence basis, no clear distinction between surface and deep water samples was found. Intensity 
Table 1

Radiocarbon values $\left(\Delta^{14} \mathrm{C}_{\text {meas }} \pm \mathrm{SD}^{\mathrm{a}}\right)$ and ages of Southern Ocean bulk SPE-DOM samples. $\Delta^{14} \mathrm{C}_{\text {calc }} \pm \mathrm{SEM} \mathrm{M}^{\mathrm{b}}$ values calculated from the combined age model c $\left(\mathrm{AM}^{\mathrm{AO}+\mathrm{SO}}\right.$, see Section 3.3). $\Delta^{14} \mathrm{C}_{\mathrm{dev}}$ is the relative difference between $\Delta^{14} \mathrm{C}_{\mathrm{calc}}$ and $\Delta^{14} \mathrm{C}_{\mathrm{meas}}$.

\begin{tabular}{|c|c|c|c|c|c|c|c|}
\hline Latitude $\left({ }^{\circ} \mathrm{S}\right)$ & Longitude $\left({ }^{\circ} \mathrm{E}\right)$ & Depth $(\mathrm{m})$ & Water mass & $\Delta^{14} \mathrm{C}_{\text {meas }}(\%)$ & Radiocarbon age BP (a) & $\Delta^{14} \mathrm{C}_{\text {calc }}(\%)$ & $\Delta^{14} \mathrm{C}_{\mathrm{dev}}(\%)$ \\
\hline 70.5 & -8.4 & 20 & AASW & $-458 \pm 12$ & $4850 \pm 180$ & $-472 \pm 11$ & 2.9 \\
\hline 69.9 & -5.5 & 800 & WDW & $-476 \pm 9$ & $5130 \pm 130$ & $-480 \pm 11$ & 0.9 \\
\hline 67.7 & -1.0 & 4500 & WSDW & $-455 \pm 9$ & $4820 \pm 130$ & $-479 \pm 11$ & 4.9 \\
\hline 67.7 & -1.0 & 200 & WDW & $-440 \pm 8$ & $4600 \pm 110$ & $-481 \pm 11$ & 8.5 \\
\hline 65.0 & -1.0 & 200 & WDW & $-443 \pm 11$ & $4640 \pm 150$ & $-484 \pm 11$ & 8.4 \\
\hline 56.0 & 12.8 & 200 & WDW & $-495 \pm 15$ & $5420 \pm 240$ & $-470 \pm 11$ & -5.4 \\
\hline 56.0 & 12.8 & 3 & AASW & $-425 \pm 15$ & $4390 \pm 210$ & $-444 \pm 11$ & 4.2 \\
\hline 53.8 & 13.5 & 3 & SPF & $-453 \pm 10$ & $4790 \pm 150$ & $-442 \pm 11$ & -2.6 \\
\hline 50.9 & 14.2 & 200 & NPF & $-432 \pm 9$ & $4480 \pm 130$ & $-458 \pm 11$ & 5.7 \\
\hline 48.4 & 14.7 & 200 & NPF & $-413 \pm 10$ & $4210 \pm 140$ & $-421 \pm 11$ & 2.0 \\
\hline
\end{tabular}

${ }^{a} \mathrm{SD}=$ standard deviation.

b $\mathrm{SEM}=$ standard error of the mean.

weighted average molecular masses, oxygen to carbon (wa $\mathrm{O} / \mathrm{C}$ ) and hydrogen to carbon (wa $\mathrm{H} / \mathrm{C}$ ) ratios were all relatively invariant $(404.7 \pm 4.7 \mathrm{Da}, \quad 0.509 \pm 0.004$, $1.246 \pm 0.007$, respectively). No significant trend was observed for any station between the data from surface and $200 \mathrm{~m}$ water depth. Samples derived from NPF, SAR and AR showed higher wa $\mathrm{H} / \mathrm{C}$ ratios. The sample from the warm AR had a significantly lower wa molecular mass $(-11.5 \mathrm{Da}$, $p=0.0013)$, accompanied by higher wa $\mathrm{H} / \mathrm{C}$ ratios $(+0.016$, $p=0.0014$ ) compared to the samples south of $45^{\circ} \mathrm{S}$.

The sharp zonal border at the Polar Front, as observed from the hydrographic data, was well reflected by the DOM degradation index $I_{\text {DEG }}$ (Fig. 1, EA Table 2). SPE-DOM samples $(0-200 \mathrm{~m})$ from the SPF had $I_{\mathrm{DEG}}$ values $>0.7$,

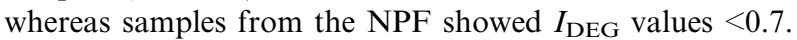
High $I_{\text {DEG }}$ values $(>0.73)$ were found in the deeper waters of the Weddell Sea, which could be attributed to WDW and WSDW. The highest $I_{\text {DEG value }(0.77) \text { was calculated }}$ in the return flow of the Weddell Gyre in the north $(200 \mathrm{~m})$. This coincides with the lowest measured $\Delta^{14} \mathrm{C}$ value $(-495 \%)$. Notably, our three deep ocean samples

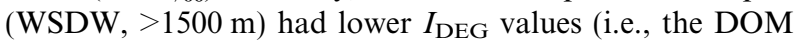
is less degraded) than the WDW (200-800 m) samples and the deepest sample from the Antarctic continental shelf $(240 \mathrm{~m})$. Moreover, the $I_{\mathrm{DEG}}$ values of the Weddell Gyre surface samples were higher than those of the East Atlantic Ocean whereas they were lower at greater depth.

PCA confirmed that essentially all samples from the southern Weddell Sea (including the shelf stations) had similar molecular patterns (Fig. 2). The average elemental ratios for these samples were also similar (EA Table 2). Despite the large congruence of the spectra, the first two principal components (PC1 and PC2) explained 36\% of the variability in the data. The scores from PC1 correlated significantly with wa molecular mass $(r=0.65, p<0.001)$, $I_{\mathrm{DEG}}(r=0.84, p<0.001)$, age $(r=0.86, p<0.001)$, temperature $(r=-0.69, p<0.001)$ and latitude $(r=-0.73$, $p<0.001)$ and scores from PC2 correlated significantly with wa nitrogen to carbon ratio (wa N/C, $r=-0.63, p<0.001$ ) and the inorganic nutrients (nitrate: $r=-0.70, p<0.001$; phosphate: $r=-0.64, p<0.001$ and silicate: $r=-0.55$, $p<0.001)$. The absolute value of the PC2 scores correlated significantly with wa $\mathrm{H} / \mathrm{C}(r=0.63, p<0.001)$.

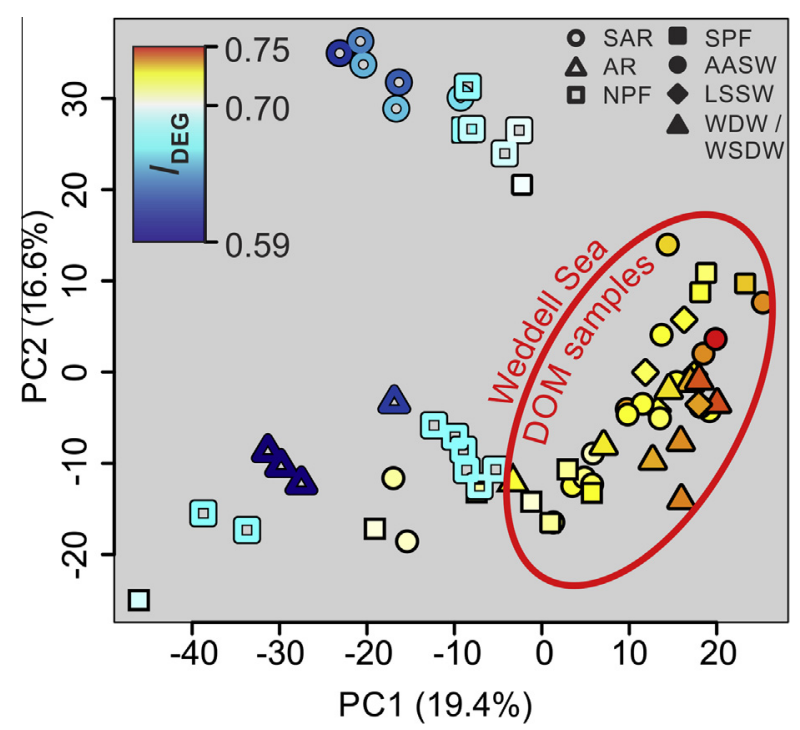

Fig. 2. Log-normalized principal component analysis for all Southern Ocean samples (number of samples $n_{\mathrm{s}}=60$ ) based on all peaks present in $\geqslant 10$ samples $(n=1663)$. North of $50^{\circ} \mathrm{S}$ : open symbols (circles: SAR, triangles: AR, squares: NPF); south of $50^{\circ} \mathrm{S}$ : filled symbols (squares: SPF, circles: AASW, diamonds: LSSW, triangles: WDW/WSDW). Colors represent the $I_{\mathrm{DEG}}$ value of each sample. Note the grouping of surface and deep DOM samples from the Weddell Sea.

\subsection{FT-ICR MS age model validation}

Our recent DOM age model (Flerus et al., 2012) relates the SPE-DOM $\Delta{ }^{14} \mathrm{C}$ values to the relative magnitudes of hundreds of peaks found in each FT-ICR MS analysis. For the selection of masses contributing to the age model only the overall coefficient of correlation with $\Delta^{14} \mathrm{C}$ is relevant, irrespective of the steepness of the slope. Use of the sum of hundreds of FT-ICR MS peaks in the age model reduces the influence of analytical variability and provides robust regression. Three approaches $(\mathrm{a}-\mathrm{c})$ were used to construct and validate the SPE-DOM age model for the Southern Ocean samples: 
a) Positive (POS) and negative (NEG) correlating FTICR MS peaks and measured $\Delta^{14} \mathrm{C}$ values $\left(\Delta^{14} \mathrm{C}_{\text {meas }}\right)$ of 24 samples from the East Atlantic Ocean (AO) were adopted from Flerus et al. (2012) and their calibration function applied to the new Southern Ocean dataset $\left(\mathrm{AM}_{\mathrm{ext}}^{\mathrm{AO}}\right)$. For the combined dataset we used a higher peak magnitude threshold of $0.01 \%$ (of the sum of all magnitudes) covering $43 \%$ of the POS and $65 \%$ of the NEG peaks from Flerus et al. (2012). The new set of 10 Southern Ocean $\Delta{ }^{14} \mathrm{C}_{\text {meas }}$ values (this study, Table 1) was then compared to the calculated $\Delta^{14} \mathrm{C}$ values $\left[\mathrm{AM}_{\mathrm{ext}}^{\mathrm{AO}}: \Delta^{14} \mathrm{C}_{\text {calc }}\right]$

b) A completely new age model for the Southern Ocean $\left(\mathrm{AM}^{\mathrm{SO}}\right)$ was established based on the 10 Southern Ocean $\Delta^{14} \mathrm{C}_{\text {meas }}$ values from this study. The model resulted in a new set of 52 POS and 46 NEG peaks, each reflecting a highly significant correlation ( $p<0.05,|r|>0.65)$ of peak magnitude with the respective bulk $\Delta^{14} \mathrm{C}_{\text {meas }}$ value. All of these $\Delta^{14} \mathrm{C}_{\text {meas }}$ values revealed a comparably higher age than the dataset from the East Atlantic Ocean, thus extending the age model $\mathrm{AM}^{\mathrm{SO}}$ towards older and presumably more degraded SPE-DOM samples.

c) All $34 \Delta^{14} C_{\text {meas }}$ values were implemented to create a combined age model (comprising 187 POS and 633 NEG masses) covering the data from both the East Atlantic and the Southern Ocean $\left(\mathrm{AM}^{\mathrm{AO}+\mathrm{SO}}\right)$ and an age range from 2000 to $5500 \mathrm{a}$.

A detailed comparison of the different approaches is presented in EA Table 3 and EA Fig. 2. In summary, all three approaches similarly reflected the trends in the $\Delta^{14} \mathrm{C}_{\text {meas }}$ values. In contrast to the combined model $\mathrm{AM}^{\mathrm{AO}+\mathrm{SO}}$ (approach c), the $\mathrm{AM}^{\mathrm{SO}}$ model (b) is biased towards a much higher age if applied to East Atlantic Ocean samples. The $\mathrm{AM}_{\mathrm{ext}}^{\mathrm{AO}}$ model (a) resulted in younger ages for the Southern Ocean samples compared to measured values (EA Fig. 2). After inclusion of 10 additional $\Delta^{14} \mathrm{C}_{\text {meas }}$ values (c), $33 \%$ of the POS and $64 \%$ of the NEG masses from the previous model $\mathrm{AM}^{\mathrm{AO}}$ (Flerus et al., 2012) were covered in the new age model $\mathrm{AM}^{\mathrm{AO}+\mathrm{SO}}$ POS and NEG lists and span the complete range of $\mathrm{O} / \mathrm{C}$ and $\mathrm{H} / \mathrm{C}$ ratios found in all 60 Southern Ocean samples (EA Fig. 3). As approach c also spanned the largest DOM age range and smallest relative standard errors of $\Delta^{14} \mathrm{C}_{\text {calc }}$, we will subsequently focus on this approach. The POS and NEG peaks that were considered for the calculation of $\left[\mathrm{AM}^{\mathrm{AO}+\mathrm{SO}}: \Delta^{14} \mathrm{C}_{\mathrm{calc}}\right]$ (in the following referred to as: $\Delta^{14} \mathrm{C}_{\text {calc }}$ ) represented $35 \%$ of all peaks found in the Southern Ocean and contributed $64.5 \pm 1.3 \%$ of the summed magnitudes in each sample.

\section{DISCUSSION}

\subsection{Southern Ocean SPE-DOM $\Delta^{14} \mathrm{C}$, DOC and FT-ICR MS data}

The very low SPE-DOM $\Delta^{14} \mathrm{C}$ surface water values in the Weddell Sea are in good agreement with previous observations from the Southern Ocean (Druffel and Bauer, 2000) and are considerably lower than surface DOC $\Delta^{14} \mathrm{C}$ values from the North Central Pacific (Williams and Druffel,
1987 ) or the Sargasso Sea (Bauer et al., 1992). Low surface (0-20 m) SPE-DOM $\Delta{ }^{14} \mathrm{C}$ values were not different to those of the deeper samples $(200-4500 \mathrm{~m}$, Table $1 ; p=0.57)$ which can be explained by the coinciding processes of upwelling of aged deep water masses (North Atlantic Deep Water transformed into WDW) and seasonal removal of fresh DOM in the surface water of the Southern Ocean (Carlson et al., 2000). Notably the Southern Ocean surface DIC $\Delta^{14} \mathrm{C}$ values are lower compared to lower latitude surface waters and this is reflected in lower POC $\Delta^{14} \mathrm{C}$ values (Druffel and Bauer, 2000). However, as fresh organic matter does not accumulate on a seasonal basis, this process cannot contribute substantially to a different reservoir age of Southern Ocean DOM.

The $200 \mathrm{~m}$ samples showed an increase in measured SPE-DOM $\Delta^{14} \mathrm{C}$ across the PF towards the north (from $-495 \%$ to $-413 \%$ ), but were still lower than the $200 \mathrm{~m}$ SPE-DOM $\Delta^{14} \mathrm{C}$ values reported for the East Atlantic Ocean $(-368 \pm 15 \%$; Flerus et al., 2012). In addition to the significant increase in surface DOC concentration north of the PF (Doval et al., 2001; this study: $p=0.0066$ ), the observed shift of DOM towards younger average age highlights the role of the ACC as a geo-ecological boundary (Longhurst, 2007). However, especially in surface waters with high productivity, large temporal (daily and seasonal) variations in $\mathrm{DO}^{14} \mathrm{C}$ can occur, as observed for the eastern North Pacific (Bauer et al., 1998; Beaupré and Druffel, 2009). The increase of surface DOC concentrations and decrease of the average age of the $200 \mathrm{~m}$ samples across the PF towards the north might be related to seasonally enhanced primary production (Geibert et al., 2010; Park et al., 2010; Korb et al., 2012) with subsequent bacterial decomposition (Rosenstock et al., 2005; Dumont et al., 2011; Pearce et al., 2011) of the fresh organic matter. In the Southern Ocean, phytoplankton production is accompanied by enhanced POC export (Carlson et al., 1998, 2000) compared to other ocean regimes. Furthermore, a shallow dissolution of the export production (i.e., sinking POC) occurs in the WG and the ACC (Usbeck et al., 2002; Jacquet et al., 2011; van der Loeff et al., 2011) which probably results in increased subsurface DOC concentrations. However, this was not observed in our data, suggesting an efficient and complete remineralization of new (dissolved) organic carbon in the WG/ACC subsurface waters.

SPE-DOM $\Delta^{14} \mathrm{C}$ values for the WDW (average: $-464 \pm 26 \%$ ) agree with values from the deep East Atlantic Ocean (SPE-DOM $\Delta \Delta^{14} \mathrm{C}$ : $-446 \pm 7 \%$; Flerus et al., 2012) and are lower than those in the deep Sargasso Sea (DOC $\Delta^{14} \mathrm{C}:-394 \pm 13 \%$; Druffel et al., 1992). These observed age differences are consistent with water mass transport patterns in the deep Atlantic Ocean: WDW originates from the old North Atlantic Deep Water (NADW) and deep water in the Sargasso Sea is mainly derived from more recently ventilated NADW. Assuming that the deep bulk DOC $\Delta^{14} \mathrm{C}$ values in the Weddell Sea and the ACC are similar (average: $-500 \%$; Druffel and Bauer, 2000), we can calculate the $\Delta^{14} \mathrm{C}$ values of the SPE discriminated fraction $X_{\text {discr }}$ (i.e., the DOM fraction not extracted with PPL) via simple isotopic mass balance. Using the average carbon 
extraction efficiency in the deep Weddell Sea $(42 \pm 6 \%$, $\left.n_{\mathrm{s}}=7\right)$, we obtain $0.42 \times(-464 \%)+0.58 \times\left(X_{\text {discr }} \Delta^{14} \mathrm{C}\right)$ $=1 \times(-500 \%)$ and thus $X_{\text {discr }} \Delta^{14} \mathrm{C}=-526 \%$. This demonstrates that the SPE discriminated fraction $X_{\text {discr }}$ is probably not primarily modern carbon. The difference of about $40 \%$ between deep ACC DOC $\Delta{ }^{14} \mathrm{C}$ and our data can also be explained by the deep circumpolar water transit time of 85 a (Stuiver et al., 1983) paralleled by a removal of younger and more labile components or temporal variability in (deep) $\Delta^{14} \mathrm{C}$ values (Bauer et al., 1998).

SPE-DOM $\Delta^{14} \mathrm{C}$, DOC concentration and FT-ICR MS derived molecular features (wa $\mathrm{H} / \mathrm{C}$ ratios, $I_{\mathrm{DEG}}$ ) independently confirm that fresh organic matter contributed little to the total Southern Ocean DOC in austral spring. The wa $\mathrm{H} / \mathrm{C}$ values were significantly lower than those of the East Atlantic Ocean surface DOM $(-0.014, p<0.001)$. Low surface DOC concentrations agreed well with previous studies south of the PF (Kähler et al., 1997; Carlson et al., 1998; Loh and Bauer, 2000; Zemmelink et al., 2008). Uniform depth distributions of DOC have also been reported for the Southern Ocean (Wedborg et al., 1998; Wiebinga and de Baar, 1998; Ogawa et al., 1999) and are consistent with our constantly low wa $\mathrm{H} / \mathrm{C}$ and high $I_{\mathrm{DEG}}$ values. The uniform wa $\mathrm{H} / \mathrm{C}$ ratios are unusual for ocean depth profiles (Kujawinski et al., 2009; Flerus et al., 2012; Hertkorn et al., 2013) but have been also reported by Koch et al. (2005) for the southwestern Weddell Sea. Low H/C ratios and high $I_{\mathrm{DEG}}$ values in the deep East Atlantic Ocean compared to the surface waters have been interpreted as a signature of reworked and degraded organic matter (Flerus et al., 2012). Further indications for the homogenous distribution of degraded DOM in the Southern Ocean were obtained from PCA that showed similar chemical compositions for the surface and deep Weddell Sea samples (Fig. 2). We conclude that the majority of SPE accessible DOM in the Weddell Sea is of old age, biologically reworked and chemically degraded. However, during spring bloom events in the Ross Sea (Carlson et al., 2000) and in the Weddell Sea (Kähler et al., 1997) increased surface DOC concentrations have been observed, which probably can also result in increased DOC $\Delta^{14} \mathrm{C}$ values.

\subsection{Degradation rate of bulk DOC modeled from SPE- DOM $\Delta^{14} \mathrm{C}$}

From the validation of our different age models, we conclude that the inclusion of new reference ages (via discrete SPE-DOM $\Delta{ }^{14} \mathrm{C}$ measurements) refined our previous age model (Flerus et al., 2012). However, all patterns and trends of the previous model were approved. POS and NEG masses contributed a higher proportion to the total summed peak magnitude than to the total number of peaks in each spectrum. This indicates that these masses represent a dominant and consistent fraction of SPE-DOM. Thus, our modeling approach allows a robust calibration of FT-ICR MS data with $\Delta^{14} \mathrm{C}$ values. As a prerequisite to an application of our age model to bulk DOC calculations, the relation of bulk DOC vs. SPE-DOM age was evaluated. The extraction efficiency for the complete dataset was $42 \pm 7 \% \quad\left(n_{\mathrm{s}}=187\right)$, and no relation of the extraction efficiency to depth, latitude or bulk DOC concentration was observed. The best linear fit of a model II regression (geometric mean regression, GMR) of [DOC] vs. SPE-DOM age was obtained by assuming that the DOC decays and ages exponentially with time, i.e., similar to a first order reaction rate. First order kinetics imply that the degradation rate is proportional to DOC concentration. It is common practice to account for an exponential rate-law by distinguishing between labile DOC with the highest removal rate, followed by semi-labile DOC with the second largest rate and so on (Hansell, 2013). However, these discrete and operationally defined fractions contrast with the concepts of size or age reactivity continua as proposed by e.g., Amon and Benner (1996) and Walker et al. (2011). The degradation of bulk DOC is a result of a superposition of multiple rates, each approximating the exponential degradation over a distinct concentration range. The concepts of the degradation continuum (Flerus et al., 2012) and the microbial carbon pump (as inferred from the successive and repetitive processing of DOM by microbes; Jiao et al., 2010) imply that degradation of DOM can be described by a single function. Ocean models describing DOC production and decay also consider an exponential decay/removal of individual DOC fractions (Schlitzer, 2007; Hansell et al., 2012). Hence, we apply Eq. (1)to describe the bulk DOC degradation:

$\ln \left(\left[\mathrm{DOC}_{\mathrm{s}}\right)=b+m \times t_{\mathrm{s}}\right.$

with $\exp (b)=a_{\mathrm{DOC}}^{\mathrm{o}}$ and $m=-k_{\mathrm{DOC}}$ :

$[\mathrm{DOC}]_{\mathrm{s}}=a_{\mathrm{DOC}}^{0} \times e^{\left(-k_{\mathrm{DOC}} \times t_{\mathrm{s}}\right)}$

where $[\mathrm{DOC}]_{\mathrm{s}}$ is the concentration of bulk DOC, $t_{\mathrm{s}}$ represents the radiocarbon age of bulk SPE-DOM in years $[a]$, $a_{\mathrm{DOC}}^{\mathrm{o}}$ is the intercept of the GMR and equivalent to [DOC] if the bulk SPE-DOM had an age of zero years $\left(t_{\mathrm{s}}=0 \mathrm{a}\right)$, and $k_{\mathrm{DOC}}$ is the reaction/degradation rate coefficient $\left[\mathrm{a}^{-1}\right]$.

GMR of all $\Delta^{14} \mathrm{C}_{\text {calc }}$ values from the age model $\mathrm{AM}^{\mathrm{AO}+\mathrm{SO}}$ and the respective bulk DOC concentrations $\left(n_{\mathrm{s}}=187\right)$ enable determination of an integrated bulk DOC degradation rate (Fig. 3). Here we use conventional radiocarbon ages of SPE-DOM samples to obtain a DOC degradation rate. Other previous approaches used mixing models of [DOC], inverse models or correlated observed net losses of total [DOC] with water mass tracers to derive exponential decay rates (e.g., Hansell et al., 2009, 2012; Carlson et al., 2010). Our model approach defines an upper limit for the degradation rate as it includes decay of ${ }^{14} \mathrm{C}$ and preferential loss of young compounds according to the degradation continuum. We calculate the age of DOM that is removed at a specific concentration level. Further, our model can only resolve long-term DOC degradation rates and thus excludes the most labile fractions. It is also limited by the accuracy of the $\Delta^{14} \mathrm{C}$ measurements ( $\left.\sim 200 \mathrm{a}\right)$. However, considering only the DOM components with low turnover rates our calculation still accounts for $>90 \%$ of the global ocean DOC inventory (Hansell et al., 2012).

The calculated degradation rate was extrapolated to the lowest deep North Central Pacific (NCP) DOC concentration $(34 \mu \mathrm{M}$, Druffel et al., 1992) resulting in a predicted DOC age of $6410 \pm 290 \mathrm{a}\left(\mathrm{NCP}\right.$ SPE-DOM $\Delta \Delta^{14} \mathrm{C}_{\text {pred }}=$ 


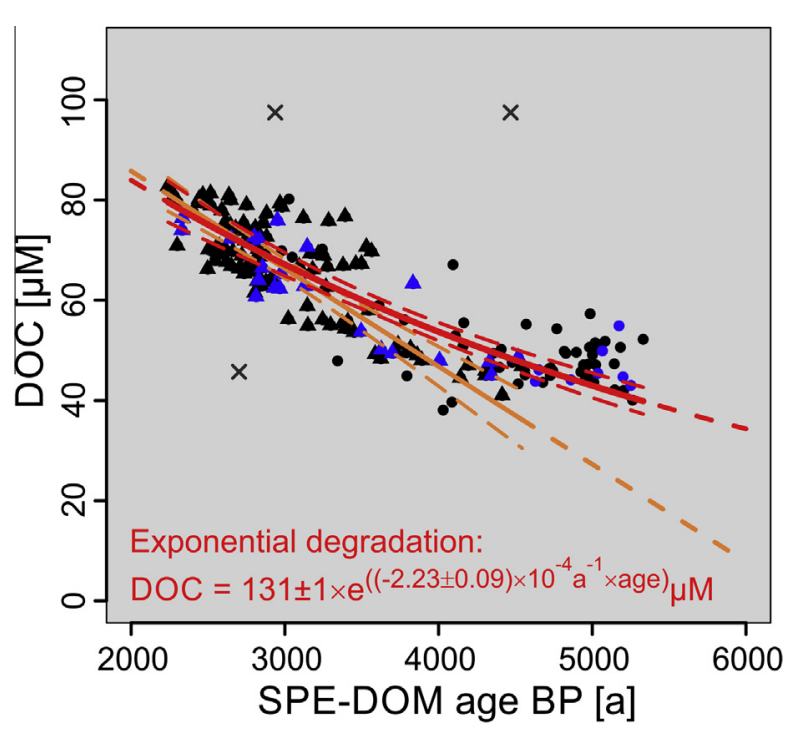

Fig. 3. Bulk DOC concentration vs. calculated age of the SPEDOM samples $\left(n_{\mathrm{s}}=187\right.$, GMR; triangles: East Atlantic, circles: Southern Ocean; blue $=\Delta{ }^{14} C_{\text {meas }}$ data). [DOC] standard deviation (mean: $5 \%$ ) and $\Delta^{14} \mathrm{C}_{\text {calc }}$ standard error of the mean (mean: $60 \mathrm{a}$ ) were omitted for clarity. Fitted exponential DOC degradation (all data and equation, red) and linear DOC degradation (only AO samples, orange) including $95 \%$ confidence intervals. Data points marked with an ' $x$ ' were treated as outliers.

$-553 \pm 16 \%$ ). Comparing this estimate of NCP $\Delta^{14} \mathrm{C}_{\text {pred }}$ with the analogous calculation using only the $34 \Delta^{14} \mathrm{C}_{\text {meas }}$ values resulted in a similar NCP SPE-DOM $\Delta^{14} \mathrm{C}_{\text {pred }}$ of $-549 \pm 37 \%$ o (EA Table 4). To estimate a minimum $\Delta^{14} \mathrm{C}$ threshold for the NCP SPE-DOM we excluded the Southern Ocean samples and applied a linear regression of [DOC] vs SPE-DOM age (Fig. 3). This approach yielded a NCP SPE-DOM $\Delta^{14} \mathrm{C}_{\text {pred }}$ of $-458.8 \pm 18.8 \%$ (EA Table 4) which is significantly higher than the reported NCP $\Delta{ }^{14} \mathrm{C}$ values (minimum $\Delta{ }^{14} \mathrm{C}=-540 \pm 3 \%$; Williams and Druffel, 1987; Druffel et al., 1992).

Complete remineralization of the bulk DOC was assumed at a threshold concentration of $<1 \mu \mathrm{M}$. Using first order kinetics this threshold concentration was reached at a DOC residence time $\left(t_{\mathrm{DOC}}\right)$ of $24,400 \pm 1100 \mathrm{a}$ $\left(\Delta{ }^{14} C_{\text {pred }}=-953 \pm 7 \%\right.$ ). This approach assumes that the observed degradation of DOC between ages of 2000 and 5500 a can be extrapolated to longer time frames, i.e., the mechanisms responsible for DOM transformation are in a steady state. We should note that the term residence time usually results from dividing a pool by a flux rate and therefore describes an average time. Since our results demonstrate that the removal of DOC is age-dependent (contrasting the definition of a residence time), we use the following definition for the term residence time $\left(t_{\mathrm{R}}\right): t_{\mathrm{R}}$ is the theoretical time after which the full suite of compounds (or a single compound) is almost completely removed from the DOM pool. We also assume that there is no additional input of the respective compound(s) to the system. Further, our "degradation rate" is different from the "removal rate" of Hansell et al. (2012) who used inorganic radiocarbon as quasi-conservative tracer of water mass circulation and
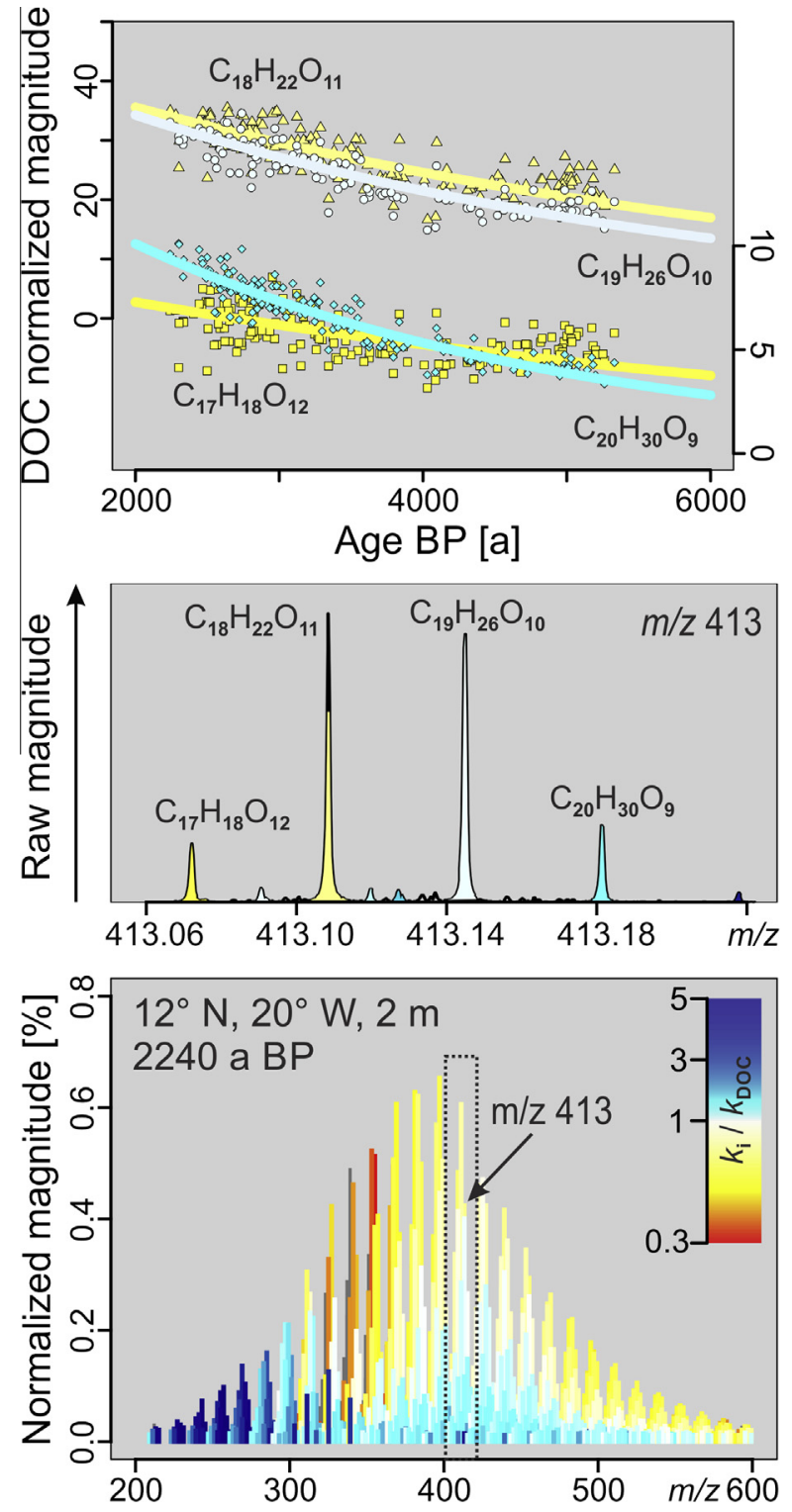

Fig. 4. The degradation continuum of a young SPE-DOM sample $\left(\Delta{ }^{14} \mathrm{C}<2500 \mathrm{a}\right)$. Top: examples of different slopes of the exponential regression of peaks at $m / z$ 413. Middle: representation of the same four compounds in the spectrum of a young surface sample, assigned with the degradation rate coefficients. Bottom: full FT-ICR MS spectrum with the typical peak magnitude distribution observed from negative mode ESI analysis of marine DOM (Koch et al., 2005; Gonsior et al., 2011). The color scale of all three figures reflect the ratio $k_{\mathrm{i}} / k_{\mathrm{DOC}}$. A ratio $k_{\mathrm{i}} / k_{\mathrm{DOC}}>1$ indicates peaks that degrade faster than bulk DOC $(n=686)$.

hence, the time which has passed since surface export. In this study, we directly used the mean age of DOM and considered two dominant processes: (i) preferential degradation of the youngest fractions and (ii) water mass transport, i.e., concurrent decay of radiocarbon. Due to the lack of an independent age tracer the degradation rate coefficient calculated from SPE-DO ${ }^{14} \mathrm{C}$ in our study is thus a superposition of multiple processes. It needs to be pointed out that the mean lifetime $(\tau)$ of the exponential decay of 
the refractory DOM fraction used by Hansell et al. (2012) describes the time after which a fraction $1 / e$ of the initial refractory DOC is not yet degraded. This requires compounds with substantially higher residence times to be present in this refractory DOC pool. Our modeled degradation rate coefficients translates into a mean lifetime of $\tau=4500 \pm 200 \mathrm{a}$, which is younger than the $16,000 \mathrm{a}$ of Hansell et al. (2012). This result is expected because our calculation included [DOC] values $>42 \mu \mathrm{M}$, thus also covering the "semi-labile" DOM fraction. Assuming that the global mechanisms for the degradation of refractory marine DOM are similar, our approach can also be used to model marine DOM ages from different origins.

\subsection{The DOM degradation continuum}

Concentrations of all chemically identifiable, naturally occurring compounds decrease with depth (age of water mass) and the proportion of chemically identifiable compounds in DOM decreases faster than the bulk DOC concentration (Kaiser and Benner, 2009). Essentially, on the time scale of the ocean mixing cycle, all compounds must degrade or they would accumulate in the ocean. We therefore assume that the abundance of all compounds detected by FT-ICR MS in SPE-DOM samples also decrease with age (Flerus et al., 2012). The limitation to "FT-ICR MS identified" compounds is a conservative constraint, because we lack information about compounds which are not covered by PPL extraction (e.g., highly polar small organic acids) or negative electrospray ionization (i.e., compounds which are highly apolar and/or cannot be deprotonated).

A consequence of the degradation continuum concept is that every sample has a distinct age which is composed of the multitude of ages of all contained DOM compounds. The different ages are the result of a continuous distribution of degradation rates. Based on this concept, it is possible to calculate semi-quantitative degradation rates for each compound. As a first approximation, we assume that the relative decrease of each peak is linearly proportional to the decrease in total DOC concentration which in turn follows a first order (exponential) degradation. Eq. (2)approximates the decrease of each peak.

$\ln \left(M_{\mathrm{i}, \mathrm{s}} \times[\mathrm{DOC}]_{\mathrm{s}}\right)=b_{\mathrm{i}}+m_{\mathrm{i}} \times t_{\mathrm{s}}$

with $\exp \left(b_{\mathrm{i}}\right)=a_{\mathrm{i}}^{\mathrm{o}}$ and $m_{\mathrm{i}}=-k_{\mathrm{i}}$ :

$M_{\mathrm{i}, \mathrm{s}} \times[\mathrm{DOC}]_{\mathrm{s}}=a_{\mathrm{i}}^{0} \times e^{\left(-k_{\mathrm{i}} \times t_{\mathrm{s}}\right)}$

where $M_{\mathrm{i}, \mathrm{s}}$ is the normalized peak magnitude of the compound ' $i$ ' in sample 's', $[D O C]_{s}$ is the DOC concentration in the original sample, $t_{\mathrm{s}}$ represents the radiocarbon age of bulk SPE-DOM in years $[a], a_{\mathrm{i}}^{\mathrm{o}}$ is equivalent to the product of $M_{\mathrm{i}, \mathrm{s}} \times[\mathrm{DOC}]_{\mathrm{s}}$ at $t_{\mathrm{s}}=0 a$, and $k_{\mathrm{i}}$ is the apparent reaction/degradation rate coefficient for the compound 'i'. The factor $M_{\mathrm{i}, \mathrm{s}} \times[\mathrm{DOC}]_{\mathrm{s}}$ is a semi-quantitative measure as it only describes the changes of a compounds' abundance in one sample relative to another sample. $M_{\mathrm{i}, \mathrm{s}} \times[\mathrm{DOC}]_{\mathrm{s}}$ can thus be referred to as "DOC normalized relative peak magnitude". We only considered peaks detected in $\geqslant 25$ samples, where the Pearson's correlation coefficient is highly significant $\left(n=1557, \quad p \leqslant 10^{-4}\right)$, covering $84 \pm 1 \%$ of the total peak magnitude and $1326 \pm 82$ peaks in each sample. The highest degradation rate is constrained by the age difference covered by the youngest 25 samples ( 400 a), thus compounds which are fully degraded prior to this limit cannot be modeled with our approach.

Due to the spectrum normalization procedure, only changes in peak magnitude relative to the total spectrum magnitude can be described, i.e., each peak is considered independently. The bulk DOC degrades with a known rate (proportional to $k_{\mathrm{DOC}}$ ) and consequently the degradation of each peak can be viewed as relative to the bulk DOC degradation $\left(k_{\mathrm{i}} / k_{\mathrm{DOC}}\right.$, Fig. 5). The rate coefficient $k_{\mathrm{i}}$ is independent of the mean peak magnitude and the highest rate coefficient $k_{\mathrm{i}}$ for an individual DOM compound was more than seven times higher than the degradation rate coefficient of bulk DOC, while the lowest rate coefficient was only $\sim 30 \%$. Assuming that the observed degradation is in steady state, we can calculate the theoretical time after which a single peak would be fully degraded $\left(M_{\mathrm{i}, \mathrm{s}} \times[\mathrm{DOC}]_{\mathrm{s}}<0.01[\% \mu \mathrm{M}]\right)$ from the intercept $a_{\mathrm{i}}^{\mathrm{o}}$ and the decay rate coefficient $k_{\mathrm{i}}$. Due to the assumed linear relation between [DOC] and $M_{\mathrm{i}, \mathrm{s}}$ and isotopic mass balance constraints we observe compounds with calculated residence times $\left(t_{\mathrm{R}}\right)$ longer than the residence time of bulk DOC $\left(t_{\text {DOC }}\right)$. For more than 1500 compounds, our approach yields calculated $t_{\mathrm{R}}$ ranging from $\sim 6$ to $>100 \mathrm{ka}$ (Fig. 5) considering that it excludes by definition the most labile compounds. As a result of mass balance considerations the degradation rate coefficients $k_{\mathrm{i}}$ are constrained by the DOC rate coefficient $k_{\mathrm{DOC}}$. The model standard error of the mean (SEM) for the compound residence times is $\sim 5 \%$ and includes the uncertainty of the age model. The normalized degradation rate coefficients for the $10 I_{\mathrm{DEG}}$ compounds (see Section 2.6 and EA Table 5) revealed that the POS peaks degrade faster than bulk DOC

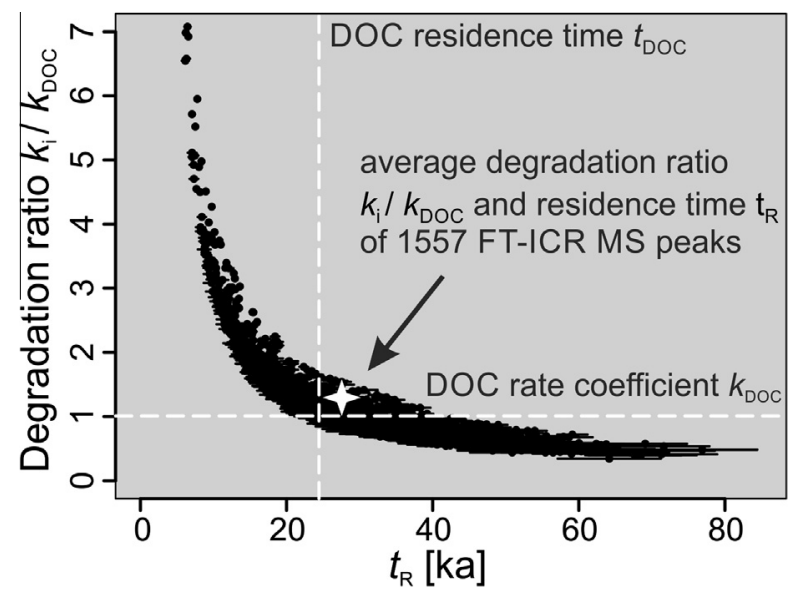

Fig. 5. Normalized degradation rate coefficient $k_{\mathrm{i}} / k_{\text {DOC }}$ vs. calculated residence time $\left(t_{\mathrm{R}}\right)$ for all peaks showing a highly significant age correlation $(n=1557)$. Peaks with a ratio $k_{\mathrm{i}} / k_{\text {DOC }}>1$ degrade faster than bulk DOC $(n=686)$. Error bars for $t_{\mathrm{R}}(\mathrm{SEM} \sim 5 \%)$ were excluded from the plot for clarity. The white star indicates the mean peak degradation rate coefficient $\left\langle k_{\mathrm{i}}\right\rangle$ and residence time $\left\langle t_{\mathrm{R}}\right\rangle$ of all peaks. White dashed lines are the respective rate coefficient $k_{\text {DOC }}$ and residence time $t_{\text {DOC }}$ for the bulk DOC degradation. 
$\left(\left\langle k_{\mathrm{i}} / k_{\mathrm{DOC}}\right\rangle_{\mathrm{POS}}=1.63\right)$ while the NEG peaks degrade slower $\left(\left\langle k_{\mathrm{i}} / k_{\mathrm{DOC}}\right\rangle_{\mathrm{NEG}}=0.75\right)$. This supports the applicability of $I_{\mathrm{DEG}}$ as a degradation state indicator for PPL extracted marine DOM samples analyzed with negative ESI mode FT-ICR MS. The mean rate coefficient $\left\langle k_{\mathrm{i}}\right\rangle=2.89 \times 10^{-4} \mathrm{a}^{-1}$ and the mean residence time $\left\langle t_{\mathrm{R}}\right\rangle=26,700 \mathrm{a}$ of all 1557 peaks were slightly higher than the values observed from the bulk DOC degradation (Fig. 5). This indicated that the high magnitude peaks may be overrepresented in the FT-ICR mass spectra.

Similar to rate calculations for bulk DOC, we only obtain net degradation rates for single mass peaks. Uncertainties in the rate calculation using mass peaks and their respective molecular formulae derive from molecular transformations within DOM: compounds could be altered with respect to molecular mass and composition and structural isomers likely also have different individual degradation rates. Moreover, net rates do not account for different pathways of degradation, such as respiration in the mesopelagial and sorption/aggregation in the bathypelagial. Each of these processes has a distinct reaction rate. In summary, all of these factors lead to a superposition of multiple rate coefficients for a single peak. High resolution structural insights from NMR studies (Woods et al., 2011; Hertkorn et al., 2013) or single mass peak fragmentation (MS/MS, Witt et al., 2009; Lechtenfeld et al., 2013) for individual components will further deepen our understanding of the structure-reactivity relationships in DOM.

The oldest bulk DOC has been dated to $\sim 6200 \mathrm{a}$ (Williams and Druffel, 1987). Druffel et al. (1992) calculated that $80 \%$ of the deep ocean DOC is recycled within every deep ocean mixing cycle, allowing for very long residence times of individual compounds. The presence of much older DOM fractions, such as lipid-like components ( $\sim 880 \%$; Loh et al., 2004) or black carbon $(-918 \%$; Ziolkowski and Druffel, 2010) imply much longer apparent residence times for these components than the mean age of the bulk DOC, suggesting a broad continuum of residence times and degradation rates. Note that it is not possible to calculate the $\mathrm{C}$-abundance of our molecular formulae in the bulk DOC because the FT-ICR mass spectra do not provide quantitative data. We assume that the statistical significant change in relative peak magnitude is proportional to the change in DOC concentration, i.e., the removal of one mole of a molecule is equivalent to a DOC decrease of one mole times the number of carbon atoms of this compound. No information is obtained relating an absolute peak magnitude difference to a concentration difference (i.e., a response factor). Therefore constraining the bulk SPE-DOM $\Delta^{14} \mathrm{C}$ values by means of compound degradation rates is currently not possible. Certainly, the error related to extrapolating the compound degradation on multiple millennia timescales is substantial, but the range of model derived residence times suggest compound ages that are substantially higher than those accessible by the radiocarbon dating methods. These compounds would contribute to a "radiocarbon dead" background DOC fraction with $\Delta^{14} \mathrm{C}=-1000 \%$ (Beaupré and Druffel, 2009).

\subsection{DOC in the Southern Ocean - too much or too old?}

In a previous study, Druffel and Bauer (2000) found that radiocarbon measurements of deep Southern Ocean DOC deviated from the regression curve between deep Atlantic and deep Pacific in a DOC $\Delta^{14} \mathrm{C}$ vs. [DOC] plot. The authors assumed a constant rate of degradation between the Sargasso Sea and the NCP and suggested that the deep Southern Ocean DOC concentrations were either too high or the DOC $\Delta^{14} \mathrm{C}$ values were too low.

For a molecular distinction of DOM derived from north and south of the PF, we compared the regression of $\ln \left(M_{\mathrm{i}, \mathrm{s}} \times[\mathrm{DOC}]_{\mathrm{s}}\right) \quad$ vs. $t_{\mathrm{s}}$ for the complete dataset $\left(n_{\mathrm{s}}=185\right.$, 'AO $+\mathrm{SO}$ ') with the sample set north of $45^{\circ} \mathrm{S}$ $\left(n_{\mathrm{s}}=138\right.$, 'AO only'). Three hundred and thirty-nine peaks significantly deviated from the regression line constructed for all samples $\left(n=225, \alpha=10^{-4}\right)$ or correlated only with the samples north of $45^{\circ} \mathrm{S}(n=114)$. In total, these 339 peaks represented $20 \%$ of the number of all peaks to which a residence time was assigned. About half of the 225 peaks had low degradation rates $\left(k_{\mathrm{i}} / k_{\mathrm{DOC}}<1\right)$. By removing these 225 peaks from the Southern Ocean samples in the model, $k_{\mathrm{i}}$ increased and $t_{\mathrm{R}}$ decreased by as much as a factor of 3.5 for the those peaks in the remaining samples (Fig. 6). According to Eq. (2), any deviation of the measured DOC concentration from the DOC degradation curve would result in a proportional shift of all DOC normalized peak magnitudes. In contrast, our data indicate that only a distinct subset of compounds reflected a statistical significant deviation from the exponential regression of the DOC normalized peak magnitudes with SPE-DOM age, which is not mirrored by the [DOC] values. We termed these compounds as "Southern Ocean ultra-refractory" (SOUR) compounds and the summed normalized magnitude of all SOUR peaks was $31.7 \pm 1.1 \%$ in the Southern Ocean samples. SOUR compounds were characterized by a lower mean molecular mass $(360 \pm 51 \mathrm{Da})$ compared to other compounds (Fig. 6, EA Table 6) but were not

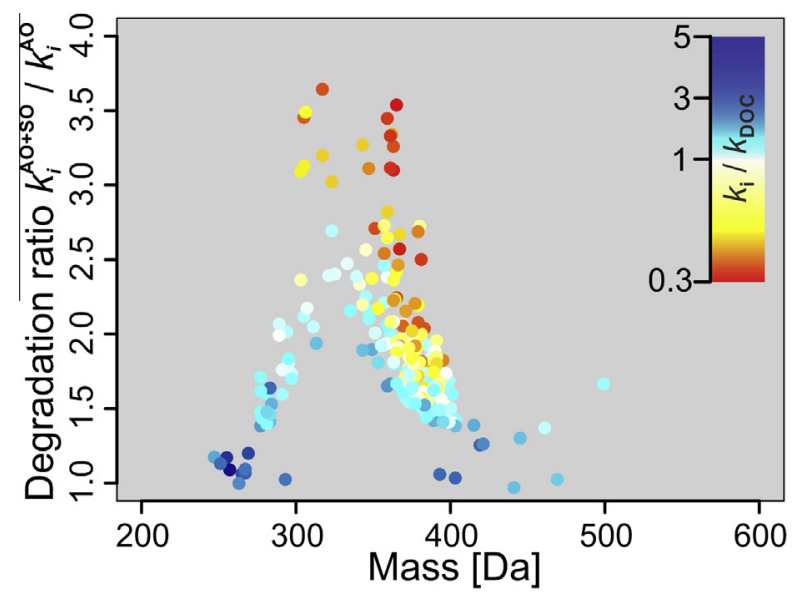

Fig. 6. The SOUR compounds. The ratio of the degradation rate coefficients $k_{\mathrm{i}}$ of both regressions models (samples 'AO + SO' and 'AO only') indicated a most pronounced $k_{\mathrm{i}}$ deviation around the molecular mass of $300-370 \mathrm{Da}(n=225)$. The color refers to the calculated ratio $k_{\mathrm{i}} / k_{\mathrm{DOC}}$ of the regression for all samples. 
significantly different in their elemental ratios. Especially, the $\mathrm{O} / \mathrm{C}$ and $\mathrm{H} / \mathrm{C}$ ratios suggest that SOUR compounds are not black carbon (Dittmar and Koch, 2006). Using the mean age of all Southern Ocean samples, we calculated that about $5 \%$ of the total peak magnitude of the Southern Ocean samples was attributed to the increase in "DOC normalized magnitude" of the SOUR peaks. We hypothesize that these peaks represent a degraded fraction of DOM and contribute to the DOC/age anomaly in the Southern Ocean.

PCA (Fig. 2) and $I_{\mathrm{DEG}}$ showed that the molecular characteristics of surface and deep Weddell Sea SPE-DOM are comparable suggesting little contribution from recently produced DOM. This agrees with the low annual primary production and substantial reworking of the fresh biomass in the Southern Ocean (Kähler et al., 1997; Carlson et al., 1998). A unique feature of the Southern Ocean and the Weddell Gyre in particular is the deep upwelling and redistribution of old water masses. As a result, radiocarbon depleted degraded DOM mixes with the surface DOM. Hansman et al. (2009) found that chemoautotrophic fixation of ${ }^{14} \mathrm{C}$ depleted carbon in the deep sea may be a significant in situ source of fresh-but-old DOM (i.e., inducing an apparent higher DOM reservoir age at depth). Based on chlorofluorocarbon data the renewal time of the WDW is long (240 a; Klatt et al., 2002) compared to the residence time of Weddell Gyre surface water (2.5-3 a; Gordon and Huber, 1990; Hoppema et al., 1999). Hence, in situ produced additional DOM would also be reworked and degraded when it mixes with the Southern Ocean surface waters. Although we assumed a similar reservoir age for the Southern Ocean and Atlantic Ocean DOM, this mechanism of upwelling and mixing of old waters could lead to a distinct subset of Southern Ocean DOM being "too old" and being represented by the SOUR compounds. Other sources of ${ }^{14} \mathrm{C}$ depleted carbon (hydrothermal vents: Lang et al., 2006; Pohlman et al., 2011; chemoautotrophy: McCarthy et al., 2011; Middelburg, 2011; black carbon: Dittmar and Koch, 2006), and advection processes (trans-

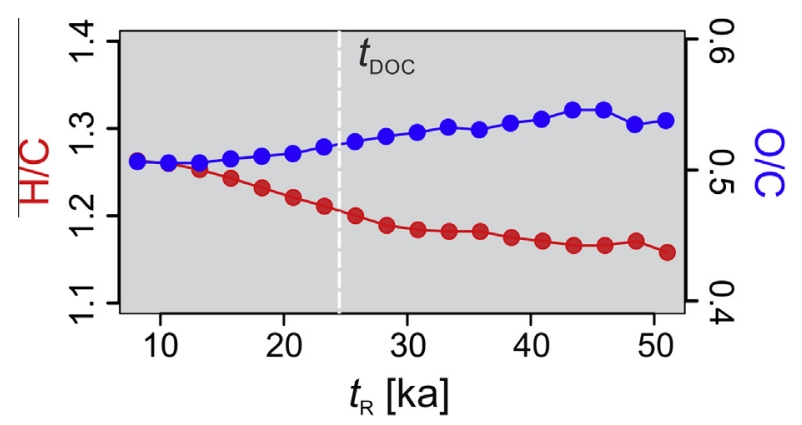

Fig. 7. Mean elemental ratios $\mathrm{H} / \mathrm{C}$ (left axis, red) and $\mathrm{O} / \mathrm{C}$ (right axis, blue) for all compounds with calculated residence times $\left(t_{\mathrm{R}}\right)$. Peaks were removed in $2.5 \mathrm{ka}$ steps from the dataset and the mean values of all remaining compounds are displayed. The first data point reflects the mean elemental composition for all compounds to which a $t_{\mathrm{R}}$ was assigned $(\mathrm{H} / \mathrm{C}=1.272 ; \mathrm{O} / \mathrm{C}=0.508, n=1557)$. See also EA Fig. 4. (For interpretation of the references to colour in this figure legend, the reader is referred to the web version of this article.) port from marginal sediments: Bauer and Druffel, 1998; deep water formation: Hansell et al., 2002) may substantially increase the deep ocean abundance of some old compounds that eventually reach the Weddell Sea surface. Another explanation for the increased abundance of the SOUR compounds is that they are not as readily degradable by heterotrophs in the Southern Ocean compared to the East Atlantic. During repeated cycling within the ACC prior to export with deep/bottom water, accumulation of even small amounts of these compounds can lead to the observed increase of the DOC normalized peak magnitude (suggesting "too much" DOC) and maintain the apparently old age of bulk DOM. We cannot ultimately decide whether the SOUR compounds result from the accumulation of compounds with mean age or the addition of older components from external sources. Both mechanisms would lead to the observed peak magnitude pattern.

\subsection{Chemical information on the most persistent DOM: the island of stability}

As a novel addition to the degradation continuum concept, the assignment of molecular formulae (here considered as "compounds") to FT-ICR MS peaks allows deduction of chemical information on the refractory DOM compounds that cycle on geological timescales in the ocean. This enables calculation of the trends of average elemental ratios and molecular mass with increasing residence time $t_{\mathrm{R}}$ for the DOM compounds (Fig. 7 and EA Fig. 4). Assuming that compounds with an assigned residence time $t_{\mathrm{R}}$ are removed from the DOM pool at the time $t_{\mathrm{R}}$, the average molecular $\mathrm{H} / \mathrm{C}$ ratio decreases with DOM aging, while the average $\mathrm{O} / \mathrm{C}$ ratio increases. This indicates that less saturated, more oxygenated compounds are most resistant to degradation. Only small changes in the $\mathrm{H} / \mathrm{C}$ and $\mathrm{O} / \mathrm{C}$ ratio, the $\mathrm{DBE}-[1 / 2 \mathrm{O}\rfloor$ value and the mass of the "removed" compounds occur after $t_{\mathrm{R}} \sim 25 \mathrm{ka} \quad$ (EA

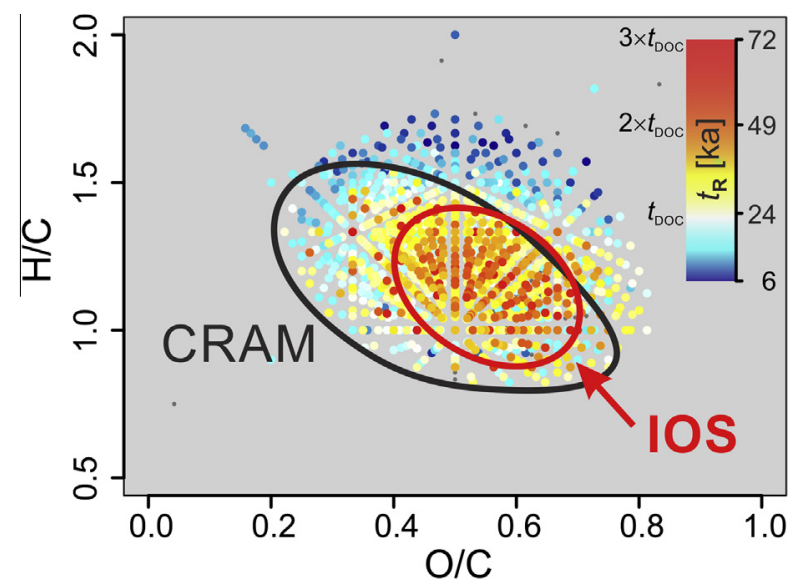

Fig. 8. The island of stability (IOS). Molecular formulae $(n=1557)$ plotted according to their elemental ratios and residence times $\left(t_{\mathrm{R}}\right)$, where yellow and red compounds have the highest $t_{\mathrm{R}}$. The approximate perimeter of CRAM-like compounds in our dataset is shown (black ellipse: $\mathrm{DBE} / \mathrm{C}=0.30-0.68$; $\mathrm{DBE} / \mathrm{H}=0.20-0.95 ; \mathrm{DBE} / \mathrm{O}=0.77-1.75$; Hertkorn et al., 2006). 
Fig. 4). This suggests that compounds with very long residence times are chemically invariant to further degradation processes. This age limit coincides with the calculated residence time for bulk DOC $\left(t_{\mathrm{DOC}}\right)$. The compounds with the longest residence times were therefore confined to a narrow range of $\mathrm{O} / \mathrm{C}$ and $\mathrm{H} / \mathrm{C}$ ratios (Fig. 8).

We propose an "island of stability" (IOS), a set of marine dissolved organic compounds with the most stable combination of elements in a distinct window of $\mathrm{H} / \mathrm{C}(1.17 \pm 0.13), \mathrm{O} / \mathrm{C}(0.52 \pm 0.10)$ and molecular mass $(360 \pm 28$ and $497 \pm 51 \mathrm{Da})$. Compounds in the IOS persist on geological timescales exceeding 1.5 times the mean residence time of DOC. In our dataset, we identified 361 molecular formulae contributing to the IOS (EA Table 7). IOS compounds represented on average $49.4 \pm 3.2 \%$ of the total magnitude in all samples and $54.2 \pm 0.4 \%$ of the total magnitude in the Weddell Sea samples. The intermediate elemental ratios of the IOS suggest that these molecular formulae also comprise the greatest number of structural realizations for any given $\mathrm{H} / \mathrm{C}, \mathrm{O} / \mathrm{C}$ and mass (Hertkorn et al., 2007). Any molecule, once it enters the DOM pool, is biologically and/or (photo-)chemically modified until it is either fully remineralized or ends up in the IOS where it is subject to a much slower degradation. A possible mechanism to modify compounds towards the IOS, can be radiolytic processes that do not substantially remineralize DOM but can alter the chemical composition of compounds towards higher oxygenation and lower saturation (Koch et al., 2012). Also, selective cleavage of side groups by exoenzymes (Arnosti, 2011) may reduce the reactivity of the products. Ogawa et al. (2001) already postulated that nonspecific, secondary activities of enzymes eventually lead to compounds which escape bacterial enzyme recognition.

The elemental ratios $(\mathrm{H} / \mathrm{C}$ and $\mathrm{O} / \mathrm{C})$ covered by IOS compounds (with $t_{\mathrm{R}}>1.5 \times t_{\mathrm{DOC}}$ ) have a substantial overlap with CRAM, a group of refractory components in marine DOM (Hertkorn et al., 2006, 2013). In our study we identified the compounds contributing to IOS by combining the modeled residence time of compounds with their elemental composition. According to our results, IOS compounds are characterized by higher relative carboxyl content (high $\left\lfloor\frac{1}{2} \mathrm{O}\right\rfloor / \mathrm{C}$ ratio) and simultaneously higher non-carboxyl unsaturation or cyclic structures (high DBE$\lfloor 1 / 2 \mathrm{O}\rfloor$ value) than non-IOS compounds (EAFig. 4). Further, $37 \%$ of all IOS compounds without $\mathrm{N}(n=291)$ were identified by Hertkorn et al. (2006) as CRAM compounds and all IOS compounds within the higher mass center ( $\sim 500 \mathrm{Da}$ ) consist solely of $\mathrm{C}, \mathrm{H}$ and $\mathrm{O}$. While these calculations disregard the huge potential isomeric space of natural organic matter (NOM) molecules (Hertkorn et al., 2008) the underlying criteria (high carboxyl content and a cyclic carbon backbone with few olefinic double bonds) also apply to CRAM compounds (Hertkorn et al., 2013). Thus these compositional similarities to CRAM are a further endorsement of the degradation continuum.

About $2 \%$ of the total DOC pool may consist of dissolved black carbon (Dittmar and Paeng, 2009) with sources in the deep sea or from land-derived pyrogenic carbon (Dittmar and Koch, 2006). Black carbon adds a very old source component to the deep-sea DOM (Ziolkowski and Druffel, 2010), affecting the radiocarbon mass balance and therefore reservoir age. However, IOS compounds are not primary black carbon molecules. This is verified by the higher $\mathrm{O} / \mathrm{C}$ and $\mathrm{H} / \mathrm{C}$ ratio as well as by the much lower aromaticity index than typically observed for black carbon compounds (Dittmar and Koch, 2006; Koch and Dittmar, 2006). Stubbins et al. (2012) previously demonstrated that highly condensed compounds are photolabile and degrade during exposition to UV-radiation in the surface ocean. This mechanism removes the black carbon from the analytical window, potentially preserving the old carbon as transformed DOM compounds. Finally, the low contribution of nitrogen and sulfur to the IOS compounds (only 19\% of the IOS compounds contain $\mathrm{N}$ compared to $31 \%$ for all peaks, and no $\mathrm{S}$ is present in any IOS compound) further suggests that these compounds are of lower nutritive value for heterotrophs.

The underlying mechanism that prevents, or at least hinders, further degradation of the IOS compounds is unclear. Our data suggest that the oxygen content in a molecule, at least in part, determines its reactivity. This is evident from a lower degradation rate coefficient for a higher number of oxygen atoms in a pseudo-homologous " $\mathrm{CH}_{4}-\mathrm{O}$ "-series (Fig. 4, top) and from the observation that $\left\lfloor\frac{1}{2} \mathrm{O}\right\rfloor / \mathrm{C}$ increases with age (EA Fig. 4). Jannasch (1967) and recently Kattner et al. (2011) hypothesized that the concentration of individual deep-sea refractory compounds is lower than the chemoreceptive threshold of prokaryotes or that the energetic yields from already highly oxygenated compounds are too low. This concept however, is in contrast to the results of LaRowe and Van Cappellen (2011) indicating that the oxidation of already highly oxidized organic compounds is thermodynamically advantageous. Our data do not support a correlation between the nominal oxidation state of carbon (NOSC, data not shown) of a compound and its degradation rate coefficient. However, a positive correlation of NOSC with the compound residence time $t_{\mathrm{R}}$ was found reflecting the observed changes of $\mathrm{O} / \mathrm{C}$ and $\mathrm{H} / \mathrm{C}$ with increasing $t_{\mathrm{R}}$ (Fig. 8). Better insights into the degradation mechanisms of NOM are required to understand this discrepancy. The lowest calculated rates are so low, that abiotic removal mechanisms seem likely to determine the ultimate fate of these compounds. Adsorption to particles and subsequent removal from the water column (Druffel and Williams, 1990), pyrogenic transformation through hydrothermal systems (Lang et al., 2006) or diapycnal mixing into surface waters may determine the decay rates of this persistent DOM fraction.

\section{CONCLUDING REMARKS}

Based on SPE-DOM, the concept of the DOM degradation continuum was confirmed, refined and extended to cover two major global oceans. The mean age of the SPE-DOM is reflected in the intrinsic molecular patterns and resulted in calculated radiocarbon ages which were in very good agreement with previous studies using bulk DOC data. The calculated mean degradation rate and residence time for this representative fraction of DOM agree well with the results from previous independent experi- 
mental and modelling studies. Our approach is applicable to other oceans worldwide providing new information on the role of DOC in the marine carbon cycle. From a holistic perspective our data indicate that addition of freshly produced DOM to the background refractory DOM does not substantially influence the subsequent degradation mechanisms of this mixed pool of organic matter despite different geo-ecological boundary conditions (e.g., phytoplankton and microbial community structure, climate regime). The results also support the concept of the microbial carbon pump.

In contrast to bulk DOC and $\Delta^{14} \mathrm{C}$ measurements, DOM degradation can now be studied on the molecular level allowing differentiation between compounds and compound classes of different lability and residence time. Radiocarbon dating and molecular information derived by FT-ICR MS provided molecular residence times much longer $(>24 \mathrm{ka})$ than any other residence time which has been proposed for an organic molecule in the ocean. In addition, these long residence times cannot be resolved with the radiocarbon dating method and would contribute to a radiocarbon-dead background DOC concentration. For the ocean's biogeochemistry, the very long residence times of a large number of DOM molecules have implications for the distribution of refractory DOC in the water column and consequently for the global amount of the most refractory DOC fraction. This persistent DOC fraction contributes to sequestered carbon that is stored for a geological time in the ocean (Jiao et al., 2010). Therefore the DOM degradation continuum should be considered in biogeochemical models as it sets chemical constraints on the degradability of refractory DOM which comprises $90 \%$ of the ocean's DOC inventory.

In the Southern Ocean, we identified a discrete group of compounds having an increased abundance. These findings are in agreement with results from Druffel and Bauer (2000) but in contrast with the standard paradigm of radiocarbon age and DOC concentration relationship in the deep ocean and contemporary concepts of marine DOC cycling. These compounds are potentially indicative of an enhanced capability of the Southern Ocean to sequester organic carbon as refractory DOM and thus long-term carbon storage. The underlying source and formation mechanism remain to be revealed and may be related to the specific oceanographic conditions in the Weddell Sea. Studying the details of this surplus of old DOC will contribute substantially to an improved understanding of the marine DOC cycle.

\section{ACKNOWLEDGEMENTS}

The authors thank the executive editor Marc Norman for handling this paper. The associate editor Elizabeth Canuel and the three anonymous reviewers are gratefully acknowledged for their thoughtful comments and contribution to improve the quality of the manuscript. We also acknowledge the master and the crew of the research vessel Polarstern and the chief scientist Olaf Boebel for professional assistance during sample collection and Lindsey Koren for radiocarbon sample preparation. We thank Stephan Frickenhaus, Mario Hoppema, and Michiel Rutgers van der Loeff for their helpful discussions during the preparation and Ruth Alheit for proof reading of this manuscript. This work was supported by the Deutsche Forschungsgemeinschaft (DFG) in the framework of the priority programme "Antarctic Research with comparative investigations in Arctic ice areas" (Grant KO 2164/8-1+2).

\section{APPENDIX A. SUPPLEMENTARY DATA}

Supplementary data associated with this article can be found, in the online version, at http://dx.doi.org/10.1016/ j.gca.2013.11.009.

\section{REFERENCES}

Amon R. M. W. and Benner R. (1994) Rapid cycling of highmolecular-weight dissolved organic matter in the ocean. Nature 369, 549-552.

Amon R. M. W. and Benner R. (1996) Bacterial utilization of different size classes of dissolved organic matter. Limnol. Oceanogr. 41, 41-51.

Arnosti C. (2011) Microbial extracellular enzymes and the marine carbon cycle. Annu. Rev. Mar. Sci. 3, 401-425.

Arrigo K. R., van Dijken G. L. and Bushinsky S. (2008) Primary production in the Southern Ocean, 1997-2006. J. Geophys. Res. Oceans 113, C8004.

Bauer J. E. (2002) Carbon isotopic composition of DOM. In Biogeochemistry of Marine Dissolved Organic Matter (eds. D. A. Hansell and C. A. Carlson). Academic Press, Elsevier Science, San Diego, USA, pp. 405-453.

Bauer J. E. and Druffel E. R. M. (1998) Ocean margins as a significant source of organic matter to the deep open ocean. Nature 392, 482-485.

Bauer J. E., Williams P. M. and Druffel E. R. M. (1992) C-14 activity of dissolved organic carbon fractions in the northcentral Pacific and Sargasso Sea. Nature 357, 667-670.

Bauer J. E., Druffel E. R. M., Williams P. M., Wolgast D. M. and Griffin S. (1998) Temporal variability in dissolved organic carbon and radiocarbon in the eastern North Pacific Ocean. $J$. Geophys. Res. Oceans 103, 2867-2881.

Beaupré S. R. and Druffel E. R. M. (2009) Constraining the propagation of bomb-radiocarbon through the dissolved organic carbon (DOC) pool in the northeast Pacific Ocean. Deep Sea Res. I 56, 1717-1726.

Beaupré S. R. and Aluwihare L. (2010) Constraining the 2component model of marine dissolved organic radiocarbon. Deep Sea Res. II 57, 1494-1503.

Carlson C. A. (2002) Production and removal processes. In Biogeochemistry of Marine Dissolved Organic Matter (eds. D. A. Hansell and C. A. Carlson). Academic Press, Elsevier Science, San Diego, USA, pp. 91-151.

Carlson C. A., Ducklow H. W., Hansell D. A. and Smith W. O. (1998) Organic carbon partitioning during spring phytoplankton blooms in the Ross Sea polynya and the Sargasso Sea. Limnol. Oceanogr. 43, 375-386.

Carlson C. A., Hansell D. A., Peltzer E. T. and Smith W. O. (2000) Stocks and dynamics of dissolved and particulate organic matter in the southern Ross Sea, Antarctica. Deep Sea Res. II 47, 3201-3225.

Carlson C. A., Hansell D. A., Nelson N. B., Siegel D. A., Smethie W. M., Khatiwala S., Meyers M. M. and Halewood E. (2010) Dissolved organic carbon export and subsequent remineralization in the mesopelagic and bathypelagic realms of the North Atlantic basin. Deep Sea Res. II 54, 1433-1445.

D’Andrilli J., Dittmar T., Koch B. P., Purcell J. M., Marshall A. G. and Cooper W. T. (2010) Comprehensive characterization of marine dissolved organic matter by Fourier transform ion 
cyclotron resonance mass spectrometry with electrospray and atmospheric pressure photoionization. Rapid Commun. Mass Spectrom. 24, 643-650.

Davis J., Kaiser K. and Benner R. (2009) Amino acid and amino sugar yields and compositions as indicators of dissolved organic matter diagenesis. Org. Geochem. 40, 343-352.

del Giorgio P. A. and Duarte C. M. (2002) Respiration in the open ocean. Nature 420, 379-384.

Dittmar T. and Koch B. P. (2006) Thermogenic organic matter dissolved in the abyssal ocean. Mar. Chem. 102, 208-217.

Dittmar T. and Paeng J. (2009) A heat-induced molecular signature in marine dissolved organic matter. Nat. Geosci. 2, 175-179.

Dittmar T., Koch B. P., Hertkorn N. and Kattner G. (2008) A simple and efficient method for the solid-phase extraction of dissolved organic matter (SPE-DOM) from seawater. Limnol. Oceanogr. Methods 6, 230-235.

Doval M. D., Alvarez-Salgado X. A., Gasol J. M., Lorenzo L. M., Miron I., Figueiras F. G. and Pedros-Alio C. (2001) Dissolved and suspended organic carbon in the Atlantic sector of the Southern Ocean. Stock dynamics in upper ocean waters. Mar. Ecol. Prog. Ser. 223, 27-38.

Druffel E. R. M. and Williams P. M. (1990) Identification of a deep marine source of particulate organic carbon using bomb C-14. Nature 347, 172-174.

Druffel E. R. M. and Bauer J. E. (2000) Radiocarbon distributions in Southern Ocean dissolved and particulate organic matter. Geophys. Res. Lett. 27, 1495-1498.

Druffel E. R. M., Williams P. M., Bauer J. E. and Ertel J. R. (1992) Cycling of dissolved and particulate organic matter in the open ocean. J. Geophys. Res. Oceans 97, 15639-15659.

Dumont I., Schoemann V., Jacquet S. H. M., Masson F. and Becquevort S. (2011) Bacterial abundance and production in epipelagic and mesopelagic waters in the Subantarctic and Polar Front zones south of Tasmania. Deep Sea Res. II 58, 2212-2221.

Flerus R., Koch B. P., Schmitt-Kopplin P., Witt M. and Kattner G. (2011) Molecular level investigation of reactions between dissolved organic matter and extraction solvents using FT-ICR MS. Mar. Chem. 124, 100-107.

Flerus R., Lechtenfeld O. J., Koch B. P., McCallister S. L., Schmitt-Kopplin P., Benner R., Kaiser K. and Kattner G. (2012) A molecular perspective on the ageing of marine dissolved organic matter. Biogeosciences 9, 1935-1955.

Foldvik A., Gammelsrød T. and Tørresen T. (1985) Hydrographic observations from the Weddell Sea during the Norwegian Antarctic Research Expedition 1976/77. Polar Res. 3, 177-193.

Geibert W., Assmy P., Bakker D. C. E., Hanfland C., Hoppema M., Pichevin L. E., Schröder M., Schwarz J. N., Stimac I., Usbeck R. and Webb A. (2010) High productivity in an ice melting hot spot at the eastern boundary of the Weddell Gyre. Global Biogeochem. Cycles 24, GB3007.

Goldberg S. J., Carlson C. A., Brzezinski M., Nelson N. B. and Siegel D. A. (2011) Systematic removal of neutral sugars within dissolved organic matter across ocean basins. Geophys. Res. Lett. 38, L17606.

Gonsior M., Peake B. M., Cooper W. T., Podgorski D. C., D'Andrilli J., Dittmar T. and Cooper W. J. (2011) Characterization of dissolved organic matter across the Subtropical Convergence off the South Island, New Zealand. Mar. Chem. 123, 99-110.

Gordon A. L. and Huber B. A. (1990) Southern Ocean winter mixed layer. J. Geophys. Res. 95, 11655-11672.

Gruber D. F., Simjouw J. P., Seitzinger S. P. and Taghon G. L. (2006) Dynamics and characterization of refractory dissolved organic matter produced by a pure bacterial culture in an experimental predator-prey system. Appl. Environ. Microbiol. 72, 4184-4191.

Hansell D. A. (2002) DOC in the global ocean carbon cycle. In Biogeochemistry of Marine Dissolved Organic Matter (eds. D. A. Hansell and C. A. Carlson). Academic Press, Elsevier Science, San Diego, USA, pp. 685-715.

Hansell D. A. (2013) Recalcitrant dissolved organic carbon fractions. Annu. Rev. Mar. Sci. 5, 421-445.

Hansell D. A., Carlson C. A. and Suzuki Y. (2002) Dissolved organic carbon export with North Pacific Intermediate Water formation. Global Biogeochem. Cycles $\mathbf{1 6}$.

Hansell D. A., Carlson C. A. and Schlitzer R. (2012) Net removal of major marine dissolved organic carbon fractions in the subsurface ocean. Global Biogeochem. Cycles 26, GB1016.

Hansell D. A., Carlson C. A., Repeta D. J. and Schlitzer R. (2009) Dissolved organic matter in the ocean: a controversy stimulates new insights. Oceanography 22, 202-211.

Hansman R. L., Griffin S., Watson J. T., Druffel E. R. M., Ingalls A. E., Pearson A. and Aluwihare L. I. (2009) The radiocarbon signature of microorganisms in the mesopelagic ocean. Proc. Natl. Acad. Sci. USA 106, 6513-6518.

Hedges J. I., Keil R. G. and Benner R. (1997) What happens to terrestrial organic matter in the ocean?. Org. Geochem. 27 195212.

Hedges J. I., Hatcher P. G., Ertel J. R. and Meyers-Schulte K. J. (1992) A comparison of dissolved humic substances from seawater with Amazon River counterparts by ${ }^{13} \mathrm{C}-\mathrm{NMR}$ spectrometry. Geochim. Cosmochim. Acta 56, 1753-1757.

Hertkorn N., Harir M., Koch B. P., Michalke B. and SchmittKopplin P. (2013) High-field NMR spectroscopy and FTICR mass spectrometry: powerful discovery tools for the molecular level characterization of marine dissolved organic matter. Biogeosciences 10, 1583-1624.

Hertkorn N., Frommberger M., Witt M., Koch B. P., SchmittKopplin P. and Perdue E. M. (2008) Natural organic matter and the event horizon of mass spectrometry. Anal. Chem. 80, $8908-8919$.

Hertkorn N., Benner R., Frommberger M., Schmitt-Kopplin P., Witt M., Kaiser K., Kettrup A. and Hedges J. I. (2006) Characterization of a major refractory component of marine dissolved organic matter. Geochim. Cosmochim. Acta 70, 29903010.

Hertkorn N., Ruecker C., Meringer M., Gugisch R., Frommberger M., Perdue E. M., Witt M. and Schmitt-Kopplin P. (2007) High-precision frequency measurements: indispensable tools at the core of the molecular-level analysis of complex systems. Anal. Bioanal. Chem. 389, 1311-1327.

Hoppema M., Fahrbach E., Stoll M. H. C. and de Baar H. J. W. (1999) Annual uptake of atmospheric $\mathrm{CO}_{2}$ by the Weddell Sea derived from a surface layer balance, including estimations of entrainment and new production. J. Mar. Syst. 19, 219-233.

Jacquet S. H. M., Lam P. J., Trull T. and Dehairs F. (2011) Carbon export production in the subantarctic zone and polar front zone south of Tasmania. Deep Sea Res. II 58, 2277-2292.

Jannasch H. W. (1967) Growth of marine bacteria at limiting concentrations of organic carbon in seawater. Limnol. Oceanogr. 12, 264-271.

Jiao N., Herndl G. J., Hansell D. A., Benner R., Kattner G., Wilhelm S. W., Kirchman D. L., Weinbauer M. G., Luo T., Chen F. and Azam F. (2010) Microbial production of recalcitrant dissolved organic matter: long-term carbon storage in the global ocean. Nat. Rev. Microbiol. 8, 593-599.

Kähler P., Bjørnsen P. K., Lochte K. and Antia A. (1997) Dissolved organic matter and its utilization by bacteria during spring in the Southern Ocean. Deep Sea Res. II 44, 341-353. 
Kaiser K. and Benner R. (2009) Biochemical composition and size distribution of organic matter at the Pacific and Atlantic timeseries stations. Mar. Chem. 113, 63-77.

Kaiser K. and Benner R. (2012) Organic matter transformations in the upper mesopelagic zone of the North Pacific: chemical composition and linkages to microbial community structure. $J$. Geophys. Res. 117, C01023.

Kattner G. (1999) Storage of dissolved inorganic nutrients in seawater: poisoning with mercuric chloride. Mar. Chem. 67, 61-66.

Kattner G. and Becker H. (1991) Nutrients and organic nitrogenous compounds in the marginal ice zone of the Fram Strait. $J$. Mar. Syst. 2, 385-394.

Kattner G., Simon M. and Koch B. P. (2011) Molecular characterization of dissolved organic matter and constraints for prokaryotic utilization. In Microbial Carbon Pump in the Ocean (eds. N. Jiao, F. Azam and S. Sanders). Science/AAAS, Washington, DC, pp. 60-61.

Kawasaki N. and Benner R. (2006) Bacterial release of dissolved organic matter during cell growth and decline: molecular origin and composition. Limnol. Oceanogr. 51, 2170-2180.

Kido Soule M. C., Longnecker K., Giovannoni S. J. and Kujawinski E. B. (2010) Impact of instrument and experiment parameters on reproducibility of ultrahigh resolution ESI FT-ICR mass spectra of natural organic matter. Org. Geochem. 41, 725-733.

Kirchman D. L., Moran X. A. G. and Ducklow H. (2009) Microbial growth in the polar oceans - role of temperature and potential impact of climate change. Nat. Rev. Microbiol. 7, 451-459.

Klatt O., Roether W., Hoppema M., Bulsiewicz K., Fleischmann U., Rodehacke C., Fahrbach E., Weiss R. F. and Bullister J. L. (2002) Repeated CFC sections at the Greenwich Meridian in the Weddell Sea. J. Geophys. Res. Oceans 107, C4.

Koch B. P. and Dittmar T. (2006) From mass to structure: an aromaticity index for high-resolution mass data of natural organic matter. Rapid Commun. Mass Spectrom. 20, 926-932.

Koch B. P., Dittmar T., Witt M. and Kattner G. (2007) Fundamentals of molecular formula assignment to ultrahigh resolution mass data of natural organic matter. Anal. Chem. 79, $1758-1763$.

Koch B. P., Witt M., Engbrodt R., Dittmar T. and Kattner G. (2005) Molecular formulae of marine and terrigenous dissolved organic matter detected by electrospray ionization Fourier transform ion cyclotron resonance mass spectrometry. Geochim. Cosmochim. Acta 69, 3299-3308.

Koch B. P., Ludwichowski K.-U., Kattner G., Dittmar T. and Witt M. (2008) Advanced characterization of marine dissolved organic matter by combining reversed-phase liquid chromatography and FT-ICR-MS. Mar. Chem. 111, 233-241.

Koch B. P., Geibert W., Lechtenfeld O. J., Witt M. and Fahl K. (2012) Natural radiation modifies the structure of organic matter in aqueous systems, 2012 Ocean Science Meeting, Salt Palace Convention Center, Salt Lake City, Utah, USA.

Korb R. E., Whitehouse M. J., Ward P., Gordon M., Venables H. J. and Poulton A. J. (2012) Regional and seasonal differences in microplankton biomass, productivity, and structure across the Scotia Sea: implications for the export of biogenic carbon. Deep Sea Res. II 59-60, 67-77.

Kujawinski E. B. and Behn M. D. (2006) Automated analysis of electrospray ionization Fourier transform ion cyclotron resonance mass spectra of natural organic matter. Anal. Chem. 78, 4363-4373.

Kujawinski E. B., Longnecker K., Blough N. V., Vecchio R. D., Finlay L., Kitner J. B. and Giovannoni S. J. (2009) Identification of possible source markers in marine dissolved organic matter using ultrahigh resolution mass spectrometry. Geochim. Cosmochim. Acta 73, 4384-4399.
Lang S. Q., Butterfield D. A., Lilley M. D., Johnson H. P. and Hedges J. I. (2006) Dissolved organic carbon in ridge-axis and ridge-flank hydrothermal systems. Geochim. Cosmochim. Acta 70, 3830-3842.

LaRowe D. E. and Van Cappellen P. (2011) Degradation of natural organic matter: a thermodynamic analysis. Geochim. Cosmochim. Acta 75, 2030-2042.

Lechtenfeld O. J., Koch B. P., Gasparovic B., Frka S., Witt M. and Kattner G. (2013) The influence of salinity on the molecular and optical properties of surface microlayers in a karstic estuary. Mar. Chem. 150, 25-38.

Lochte K., Bjørnsen P. K., Giesenhagen H. and Weber A. (1997) Bacterial standing stock and production and their relation to phytoplankton in the Southern Ocean. Deep Sea Res. II 44, 321-340.

Loh A. N. and Bauer J. E. (2000) Distribution, partitioning and fluxes of dissolved and particulate organic $\mathrm{C}, \mathrm{N}$ and $\mathrm{P}$ in the eastern North Pacific and Southern Oceans. Deep Sea Res. I 47, 2287-2316.

Loh A. N., Bauer J. E. and Druffel E. R. M. (2004) Variable ageing and storage of dissolved organic components in the open ocean. Nature 430, 877-881.

Longhurst A. (2007) Ecological geography of the sea, second ed. Academic Press, Burlington, San Diego, London.

McCarthy M. D., Beaupre S. R., Walker B. D., Voparil I., Guilderson T. P. and Druffel E. R. M. (2011) Chemosynthetic origin of C-14-depleted dissolved organic matter in a ridgeflank hydrothermal system. Nat. Geosci. 4, 32-36.

McNichol A. P. and Aluwihare L. I. (2007) The power of radiocarbon in biogeochemical studies of the marine carbon cycle: insights from studies of dissolved and particulate organic carbon (DOC and POC). Chem. Rev. (Washington, DC, USA) 107, 443-466.

Middelburg J. J. (2011) Chemoautotrophy in the ocean. Geophys. Res. Lett. 38, L24604.

Mopper K., Zhou X. L., Kieber R. J., Kieber D. J., Sikorski R. J. and Jones R. D. (1991) Photochemical degradation of dissolved organic carbon and its impact on the oceanic carbon cycle. Nature 353, 60-62.

Ogawa H., Fukuda R. and Koike I. (1999) Vertical distributions of dissolved organic carbon and nitrogen in the Southern Ocean. Deep Sea Res. I 46, 1809-1826.

Ogawa H., Amagai Y., Koike I., Kaiser K. and Benner R. (2001) Production of refractory dissolved organic matter by bacteria. Science 292, 917-920.

Orsi A. H., Whitworth T. and Nowlin W. D. (1995) On the meridional extent and fronts of the Antarctic Circumpolar Current. Deep Sea Res. I 42, 641-673.

Park J., Oh I.-S., Kim H.-C. and Yoo S. (2010) Variability of SeaWiFs chlorophyll-a in the southwest Atlantic sector of the Southern Ocean: strong topographic effects and weak seasonality. Deep Sea Res. I 57, 604-620.

Pearce I., Davidson A. T., Thomson P. G., Wright S. and van den Enden R. (2011) Marine microbial ecology in the sub-Antarctic Zone: rates of bacterial and phytoplankton growth and grazing by heterotrophic protists. Deep Sea Res. II 58, 2248-2259.

Pearson K. (1901) On lines and planes of closest fit to systems of points in space. Philos. Mag. Ser. 6(2), 559-572.

Pohlman J. W., Bauer J. E., Waite W. F., Osburn C. L. and Chapman N. R. (2011) Methane hydrate-bearing seeps as a source of aged dissolved organic carbon to the oceans. Nat. Geosci. 4, 37-41.

Repeta D. J. and Aluwihare L. I. (2006) Radiocarbon analysis of neutral sugars in high-molecular-weight dissolved organic carbon: implications for organic carbon cycling. Limnol. Oceanogr. 51, 1045-1053. 
Rosenstock B., Zwisler W. and Simon M. (2005) Bacterial consumption of humic and non-humic low and high molecular weight DOM and the effect of solar irradiation on the turnover of labile DOM in the Southern Ocean. Microb. Ecol. 50, 90-101.

Rossello-Mora R., Lucio M., Pena A., Brito-Echeverria J., LopezLopez A., Valens-Vadell M., Frommberger M., Anton J. and Schmitt-Kopplin P. (2008) Metabolic evidence for biogeographic isolation of the extremophilic bacterium Salinibacter ruber. ISME J. 2, 242-253.

Sabine C. L., Feely R. A., Gruber N., Key R. M., Lee K., Bullister J. L., Wanninkhof R., Wong C. S., Wallace D. W. R., Tilbrook B., Millero F. J., Peng T. H., Kozyr A., Ono T. and Rios A. F. (2004) The oceanic sink for anthropogenic CO(2). Science 305, $367-371$.

Schlitzer R. (2007) Assimilation of radiocarbon and chlorofluorocarbon data to constrain deep and bottom water transports in the world ocean. J. Phys. Oceanogr. 37, 259-276.

Sleighter R. L., Lie Z. F., Xue J. H. and Hatcher P. G. (2010) Multivariate statistical approaches for the characterization of dissolved organic matter analyzed by ultrahigh resolution mass spectrometry. Environ. Sci. Technol. 44, 7576-7582.

Sleighter R. L., Chen H. M., Wozniak A. S., Willoughby A. S., Caricasole P. and Hatcher P. G. (2012) Establishing a measure of reproducibility of ultrahigh-resolution mass spectra for complex mixtures of natural organic matter. Anal. Chem. 84, 9184-9191.

Sofer Z. (1980) Preparation of carbon dioxide for stable carbon isotope analysis of petroleum fractions. Anal. Chem. 52, 1389-1391.

Stubbins A., Niggemann J. and Dittmar T. (2012) Photo-lability of deep ocean dissolved black carbon. Biogeosciences 9, 16611670.

Stuiver M. and Polach H. A. (1977) Reporting of C-14 data discussion. Radiocarbon 19, 355-363.

Stuiver M., Quay P. D. and Ostlund H. G. (1983) Abyssal water carbon-14 distribution and the age of the world oceans. Science 219, 849-851.

Tfaily M. M., Podgorski D. C., Corbett J. E., Chanton J. P. and Cooper W. T. (2011) Influence of acidification on the optical properties and molecular composition of dissolved organic matter. Anal. Chim. Acta 706, 261-267.

Tziotis D., Hertkorn N. and Schmitt-Kopplin P. (2011) Kendrickanalogous network visualisation of ion cyclotron resonance Fourier transform mass spectra: improved options for the assignment of elemental compositions and the classification of organic molecular complexity. Eur. J. Mass Spectrom. 17, 415-421.
Usbeck R., van der Loeff M. M. R., Hoppema M. and Schlitzer R. (2002) Shallow remineralization in the Weddell Gyre. Geochem. Geophys. Geosyst. 3.

van der Loeff M. M. R., Cai P. H. H., Stimac I., Bracher A., Middag R., Klunder M. B. and van Heuven S. (2011) Th-234 in surface waters: distribution of particle export flux across the Antarctic Circumpolar Current and in the Weddell Sea during the GEOTRACES expedition ZERO and DRAKE. Deep Sea Res. II 58, 2749-2766.

Vogel J. S., Nelson D. E. and Southon J. R. (1987) C-14 background levels in an accelerator mass spectrometry system. Radiocarbon 29, 323-333.

Walker B. D., Beaupré S. R., Guilderson T. P., Druffel E. R. M. and McCarthy M. D. (2011) Large-volume ultrafiltration for the study of radiocarbon signatures and size vs. age relationships in marine dissolved organic matter. Geochim. Cosmochim. Acta 75, 5187-5202.

Wedborg M., Hoppema M. and Skoog A. (1998) On the relation between organic and inorganic carbon in the Weddell Sea. $J$. Mar. Syst. 17, 59-76.

Wiebinga C. J. and de Baar H. J. W. (1998) Determination of the distribution of dissolved organic carbon in the Indian sector of the Southern Ocean. Mar. Chem. 61, 185-201.

Willey J. D., Kieber R. J., Eyman M. S. and Avery G. B. (2000) Rainwater dissolved organic carbon: concentrations and global flux. Global Biogeochem. Cycles 14, 139-148.

Williams P. M. and Druffel E. R. M. (1987) Radiocarbon in dissolved organic matter in the Central North Pacific Ocean. Nature 330, 246-248.

Witt M., Fuchser J. and Koch B. P. (2009) Fragmentation studies of fulvic acids using collision induced dissociation Fourier transform ion cyclotron resonance mass spectrometry. Anal. Chem. 81, 2688-2694.

Woods G. C., Simpson M. J., Koerner P. J., Napoli A. and Simpson A. J. (2011) HILIC-NMR: toward the identification of individual molecular components in dissolved organic matter. Environ. Sci. Technol. 45, 3880-3886.

Zemmelink H. J., Houghton L., Dacey J. W. H., Stefels J., Koch B. P., Schröder M., Wisotzki A., Scheltz A., Thomas D. N., Papadimitriou S., Kennedy H., Kuosa H. and Dittmar T. (2008) Stratification and the distribution of phytoplankton, nutrients, inorganic carbon, and sulfur in the surface waters of Weddell Sea leads. Deep Sea Res. II 55, 988-999.

Ziolkowski L. A. and Druffel E. R. M. (2010) Aged black carbon identified in marine dissolved organic carbon. Geophys. Res. Lett. 37, L16601. 